\title{
Efecto del enrollado y enderezado en las propiedades mecánicas de barras de acero de diámetro medio y grande fabricadas en rollo
}

\section{Effects of winding and straightening of medium and large diameter reinforcing bars manufactured in coils in their mechanical properties}

\author{
J. M. Bairan $(*)$, A. R. Mari(*), H. Ortega(**), J. C. Rosa(*)
}

Recepción/Received: 1-VI-10

Aceptación/Accepted: 29-X-10

RESUMEN

Las armaduras en rollo ofrecen grandes ventajas logísticas y medioambientales, por lo que tienden a fabricarse en diámetros medios y grandes. La fabricación introduce complejas historias de carga y temperatura produciendo tensiones residuales. En este artículo se presenta un estudio experimental y numérico sobre la incidencia en las propiedades mecánicas de las barras en rollo, principalmente en la ductilidad. La experimentación incluye fases de caracterización de las zonas del núcleo y corona de la barra, y la comparación entre barras rectas y barras enrolladas idénticas enderezadas en condiciones de laboratorio. El estudio numérico se basa en un modelo constitutivo de endurecimiento mixto y permite considerar la geometría real de la barra y las altas temperaturas involucradas. Se identifican los orígenes y distribuciones de las tensiones residuales y los principales efectos que se producen en las propiedades mecánicas. Finalmente, se recomiendan radios de rollos para controlar la pérdida de ductilidad.

Palabras clave: Armaduras en rollo, ductilidad, tensiones residuales, endurecimiento mixto.

\section{SUMMARY}

Reinforcing bars produced in coils offer important logistic and environmental advantages, for this reason there is a tendency to produce them in medium and larger diameters. Fabrication introduces complex load and temperature histories producing residual stresses. This paper presents an experimental and theoretical study of the incidence in the mechanical properties of reinforcing bars manufactured in coils, mainly in terms of ductility. Experimentation included phases of characterization of the core and crown regions of the bar, and comparison of straight bars and identical rolled bars straightened in laboratory conditions. Numerical study is based in a mixed-hardening constitutive model and allows considering the actual geometry of the bar as well as the high temperatures involved. The model identifies the origin and distribution of residual stresses and the main effects in the mechanical properties of the bars. Finally, recommendations are given regarding coil radius in order to control bar ductility.

Keywords: Coiled rebars, ductility, residual stresses, mixed-hardening.

\footnotetext{
(*) Universitat Politècnica de Catalunya (UPC) (Barcelona, España).

(**) Compañía Española de Laminación (CELSA) (Barcelona, España).
} 


\section{INTRODUCCIÓN}

La elaboración y comercialización de armaduras en forma de rollo se ha realizado tradicionalmente para barras de diámetro pequeño ( $\varnothing \leq 12 \mathrm{~mm}$ ), siendo utilizadas en la elaboración de cercos o en armados secundarios de piezas de hormigón armado. Estas barras necesitan ser enderezadas mediante máquinas específicas (estribadoras) que pueden ser programadas para dar la contra-curvatura necesaria para proporcionar la forma final de la barra que será dispuesta dentro de la pieza de hormigón. La versatilidad de este producto junto con el abanico de ventajas relativas a transporte, manipulación, acopio, eliminación de despuntes y demás aspectos de carácter logístico y ambiental hacen que esta forma de producción resulte atractiva de cara a la industrialización y sostenibilidad de la construcción de elementos de hormigón armado. Adicionalmente, en la gran mayoría de casos, estos aceros se obtienen a partir de materiales reciclados en hornos eléctricos y procesos TEMPCORE ${ }^{\circledR}$, que proporcionan barras de alta resistencia y ductilidad.

Un paso natural hacia la completa industrialización de la construcción es la producción en rollo de barras de diámetros medios y altos de cualquier tipo de acero; incluyendo los aceros con características especiales de ductilidad. Sin embargo, el enrollado implica inducir grandes curvaturas justo después de la aplicación del proceso TEMPOCORE ${ }^{\circledR}$ encontrándose la barra sometida a altas temperaturas con distribuciones de tensiones no uniformes. Posteriormente, a temperatura ambiente, las barras se han de enderezar en taller u obra, proceso que conlleva necesariamente la plastificación de algunas fibras. Adicionalmente, el proceso TEMPCORE ${ }^{\circledR}$ genera distribuciones heterogéneas de las características del material por la diferente cristalización de las diversas regiones de la sección transversal.

Se ha observado que los aspectos anteriormente citados afectan a las propiedades mecánicas de las barras, tales como modificación del límite elástico, cambio de la forma de la meseta elasto-plástica del diagrama tensióndeformación, la cual puede incluso eliminarse, reducción de la ductilidad, etc. Estos efectos son más apreciables en los diámetros mayores que son los comúnmente utilizados para armaduras principales de flexión en elementos estructurales.

En Europa se producen armaduras de acero soldable con alta o muy alta ductilidad y aceros con un límite elástico de 400 y 500 MPa bajo diferentes nomenclaturas, ver Tabla 1. Las diversas normativas proporcionan diferentes grados de ductilidad en función de la deformación máxima alcanzada en el ensayo de tracción directa. En concreto, la normativa Española (1) define dos grados de ductilidad diferentes para barras soldadas: S y SD para

\section{INTRODUCTION}

Reinforcing steel coils have been traditionally manufactured in small nominal diameters ( $\varnothing \leq 12 \mathrm{~mm}$ ) and they have been mainly used as stirrups or secondary reinforcements in reinforced concrete $(R C)$ elements. These bars need to be straightened on special machines which may be programmed to automatically bend the bars in the required form letting them ready for the final position in the concrete element. The versatility of this product together with the many advantages in transportation, handling, stock, virtual elimination of short bars wastes and other logistic aspects make this format especially relevant for the industrialization and sustainability of concrete construction. Moreover, in most cases, these type of steels are produced from recycled metals in electric furnaces and by TEMPCORE® process giving high strength and ductility to the bars.

A natural step towards fully industrialization of construction is to produce coils of bars of larger diameter, including all steel grades and ductility classes. However, it should be considered that the production process necessarily include bending the bars to very large curvatures just after application of TEMPOCORE ${ }^{\circledR}$ process, hence the bars are also at high temperatures with non-uniform distribution. Latter, at environment temperature, bars have to be straightened in workshops inducing yielding of some fibres. Moreover, heterogeneous material distribution results from TEMPCORE ${ }^{\circledR}$ process due to the different crystallization achieved at different regions of the cross-section.

It has been observed that all these aspects affect the mechanical properties and the stress-strain curves of the final straight bar. Changes on the yielding stress, modifications or even elimination of the yielding plateau shape and reduction of ductility are examples of such effects, which are more noticeable for larger diameters intended for principal reinforcements of structural elements.

Weldable reinforcement with high and very high ductility and steel yield stress of 400 and $500 \mathrm{MPa}$ are produced in Europe under different denominations, see Table 1. Different ductility requirements may be considered in the codes attending to the strain at maximum stress in the standard tension test. In particular, Spanish Standards (1) defines two different ductility grades for weldable reinforcement: $S$ for normal ductility and $S D$ for high 
Efecto del enrollado y enderezado en las propiedades mecánicas de barras de acero de diámetro medio y grande fabricadas en rollo Effects of winding and straightening of medium and large diameter reinforcing bars manufactured in coils in their mechanical properties

Tabla 1 / Table 1

Denominación y normativas para el grado 500 MPa barras de acero dúctil. Denomination and standards for grade $500 \mathrm{MPa}$ ductile steel bars.

\begin{tabular}{|c|c|c|}
\hline País / Country & Norma / Standard & Denominación $\mathbf{f}_{\mathbf{y}}=\mathbf{5 0 0}$ Mpa / Denomination for $\boldsymbol{f}_{\mathbf{y}}=\mathbf{5 0 0 ~} \mathbf{M P a}$ \\
\hline Belgica/ Belgium & NBN A-24-302 & BE-500S \\
\hline Francia/ France & NF A35-016-1996 & FeR 500-3 \\
\hline Alemania/ Germany & DIN 488 500 S-IV \\
\hline Paises Bajos/ Netherlands & NEN 6008 & FEB 500 HWL \\
\hline España/ Spain & UNE 36-065 EX 200 & B500S and B500SD \\
\hline Suiza/ Switzerland & SIA 262/1 2003 & Tempcore 500-A \\
\hline Gran Bretaña/ United Kingdom & BS 4449:2005 B500B \\
\hline
\end{tabular}

aceros de ductilidad normal y alta ductilidad, con deformaciones características bajo carga máxima de 0,05 y 0,075 , respectivamente.

La característica especial de las barras SD radica en su alta ductilidad; de hecho la Instrucción Española de Hormigón Estructural EHE-08 (2) obliga el uso de estas barras en zonas de sismicidad elevada. Por ello, es importante conocer cuáles son los efectos del enderezado en los parámetros estructurales de las armaduras principales de diámetros medios y grandes. Sobre todo, es necesario conocer los fenómenos asociados al proceso para poder extraer recomendaciones para su fabricación y fijar protocolos de enderezado que ayuden a garantizar que las prestaciones de estas barras sean equivalentes a las de las barras rectas tradicionales.

Existe diversa bibliografía relacionada con la caracterización de las diversas fases asociadas al proceso TEMPCORE®. Cabe destacar los trabajos de Bontcheva y Petzov (3), por la simulación realizada del proceso de fabricación y optimización de resistencia y ductilidad de barras. Yong-Soon y Byung-Min (4) reprodujeron el campo de temperaturas y la evolución de la microestructura durante el proceso de fabricación. El comportamiento del material bajo altas temperaturas fue investigado por Nikolau y Papadimitriou (5). Además, la respuesta del material bajo cargas de fatiga de barras rectas TEMPCORE ${ }^{\circledR}$ ha sido investigado por Zheng y Abel (6), entre otros.

El objetivo de este artículo es investigar las variaciones en las propiedades mecánicas de las armaduras suministradas en rollo, causadas por las diversos etapas de fabricación, en especial analizando los efectos del enrollado y enderezado. A tal fin, se ha desarrollado un modelo numérico para simular los efectos de las tensiones residuales generadas a lo largo de todo el proceso de producción en la curva tensión-deformación de las barras enderezadas. El modelo ha sido calibrado mediante una campaña experimental llevada a cabo por los autores, en la que se ensayaron muestras tomadas en la planta de laminación antes y después del embobinado ductility steel, with characteristic strain under maximum load of 0.05 and 0.075 , respectively.

The particular characteristic of $S D$ bars is the high ductility; hence in the Spanish Concrete Code (2) these bars are mandatory in high seismic zones. It is, therefore, important to know what are the structural parameters of main longitudinal reinforcing bars, especially of medium and large diameters, coming from straightened coils. Moreover, it is necessary to fully understand the phenomena involved in the process in order derive recommendations for production and straightening protocols that help guaranteeing material performance levels equivalent to those of traditional reinforcing bars.

Many studies exist in the literature regarding the characterization of the different phases of TEMPCORE ${ }^{\circledR}$ bars. Among others, the works of Bontcheva and Petzov (3) are remarkable in the simulation of the fabrication process and optimization of the strength and ductility of bars. Yong-Soon and Byung-Min (4) simulated the temperature field and the evolution of the microstructure during fabrication. The material behaviour under high temperature was investigated by Nikolau and Papadimitriou (5). Also, the material response under fatigue loading of TEMPCORE $($ straight bars was investigated by Zheng and Abel (6) among others.

The objective of this paper is to investigate the variations on the mechanical properties of steel reinforcement coils due to the whole production steps focusing in the effects of coiling and straightening. For this purpose, a numerical model has been developed to simulate the effects of the residual stresses generated by the whole manufacturing process on the stress-strain curve of straightened bars is presented. The model has been calibrated with an experimental campaign in which samples from a lamination plant before and after coiling and after straightening the bars have been tested in laboratory and workshop conditions. Bars with different 
y después del enderezado. Se eligieron barras de diferentes diámetros, extraídas de diferentes puntos de la bobina $y$, por tanto, con diferentes radios de enrollado y condiciones de enfriamiento. Posteriormente las muestras se ensayaron a tracción en laboratorio, de acuerdo con la normativa de ensayo correspondiente, a fin de obtener curvas tensión-deformación y características mecánicas de barras embobinadas y enderezadas.

Se ha desarrollado una ecuación constitutiva del acero que incluye un modelo de endurecimiento mixto isótropo-cinemático. Este tipo de endurecimiento ha resultado necesario para reproducir adecuadamente el comportamiento del material frente a los complejos fenómenos que tienen lugar, tales como carga y descarga hasta las grandes deformaciones exigidas por el enrollado y enderezado, o existencia de altas temperaturas con distribución no uniforme en la sección. Se ha definido un parámetro de endurecimiento mixto $(\beta)$, cuyo valor es 0 para endurecimiento totalmente cinemático y 1 para endurecimiento isótropo y puede tomar valores intermedios para comportamientos intermedios. Este parámetro se calibró, para los aceros estudiados, a partir de la campaña experimental realizada. El modelo constitutivo se ha implementado en un modelo de análisis seccional basado en una discretización por fibras, el cual ha sido verificado con los resultados experimentales. Una vez calibrado, el modelo se ha utilizado de forma sistemática para simular los procesos de embobinado y enderezado, realizando un estudio paramétrico. Como resultado de este estudio, se propone una expresión que relaciona los diámetros de la barra y de la bobina con el porcentaje de reducción de la ductilidad en barras enderezadas. Finalmente se analizan los resultados y se extraen las conclusiones más importantes del estudio realizado.

\section{DESCRIPCIÓN DEL MATERIAL}

Las barras de acero soldable de alta ductilidad de 400 $\mathrm{MPa}$ y $500 \mathrm{MPa}$ pueden fabricarse utilizando el proceso TEMPCORE ${ }^{\circledR}$. Esta técnica consiste en un temple severo mediante la aplicación de vapor a alta presión de la parte de la superficie de la barra cuando ésta sale del tren de laminación. Posteriormente se reduce la temperatura externa de $800{ }^{\circ} \mathrm{C}$ a $400{ }^{\circ} \mathrm{C}$, aproximadamente. Se produce un revenido de la barra alimentado por el calor residual que conserva el núcleo, que reduce las tensiones residuales generadas durante el temple de ésta.

En este proceso se forma un material de características heterogéneas con una corona exterior de tipo martensítico, caracterizada por una elevada dureza y resistencia mecánica. Por otro lado, el núcleo de la barra está compuesto por una estructura de naturaleza ferrítico-perlítica con una elevada ductilidad. Entres ambas capas nominal diameter, from different locations within the coil and different loop diameters, were selected. Afterwards, traction tests according to the current standards were performed in order to determinate the stress-strain curves of bended and un-bended steel and their mechanical parameters.

A constitutive model of steel has been developed in this study to accurately represent loading and unloading up to the large strains involved in the process, high temperatures and non-uniform distribution of temperature. The model includes a mixed kinematicisotropic hardening rule needed to properly reproduce some of the phenomena observed. A mix hardening parameter $(\beta)$ was defined that ranges from 0 to 1 for fully kinematic hardening to fully isotropic hardening respectively. This parameter was calibrated against the obtained properties of the steel. The model was implemented into a fibre sectional model and extensively used for simulating the manufacture and straightening processes in a complete parametric study. As a result of this study, an expression has been proposed which relates the bar and coil diameters with the reduction of ductility of straightened bars. Finally, the results are discussed and the most relevant conclusions and recommendations of the research work are drawn.

\section{MATERIAL DESCRIPTION}

Weldable-high ductility steel bars with grades of $400 \mathrm{MPa}$ and $500 \mathrm{MPa}$ can be produced using TEMPCORE® process. This technique consists on a severe tempering by applying high pressure vapour on the bar's surface just after coming out of the lamination train. Hence, external temperature is reduced approximately from $800^{\circ} \mathrm{C}$ to $400^{\circ} \mathrm{C}$. Fed by the internal heat that still exists in the bar's core, a further reheating takes place which helps to reduce residual stresses produced during tempering.

In this process an heterogeneous material forms with a martensite structure in the outer surface, characterized by a very high strength and yielding stress, and an internal core composed by a combination of ferrite and pearlite structure characterized by its very high ductility. Between the two main structures, a bainitic transition 
encontramos una interfase bainítica de propiedades intermedias entre corona exterior y núcleo. La Figura 1 muestra una preparación metalográfica de $20 \mathrm{~mm}$ de diámetro donde son apreciables las tres capas de material. Por regulación de la presión de vapor, el espesor de la corona de martensita puede modificarse controlando la resistencia y ductilidad de la barra completa. Este proceso permite fabricar barras de acero de alto límite elástico y altos niveles de deformación a partir de acero sin inclusión de aditivos caros como el vanadio o el niobio.

Posteriormente las barras se enrollan formando una bobina. En este proceso la barra se somete a grandes deformaciones bajo temperaturas moderadamente altas. Estas deformaciones son mayores en la corona exterior zona donde se encuentra la martensita, de naturaleza menos dúctil.

Antes de utilizar definitivamente la barra como armadura pasiva, ésta se endereza en taller para obtener las longitudes de corte necesarias. De esta forma se eliminan las pérdidas por despuntes en la elaboración de la ferralla. Durante el enderezado las barras se curvan en sentido opuesto al del embobinado y se introducen grandes deformaciones a temperatura ambiente. Se debe plastificar la barra para obtener la contra-curvatura necesaria que proporcione una directriz recta.

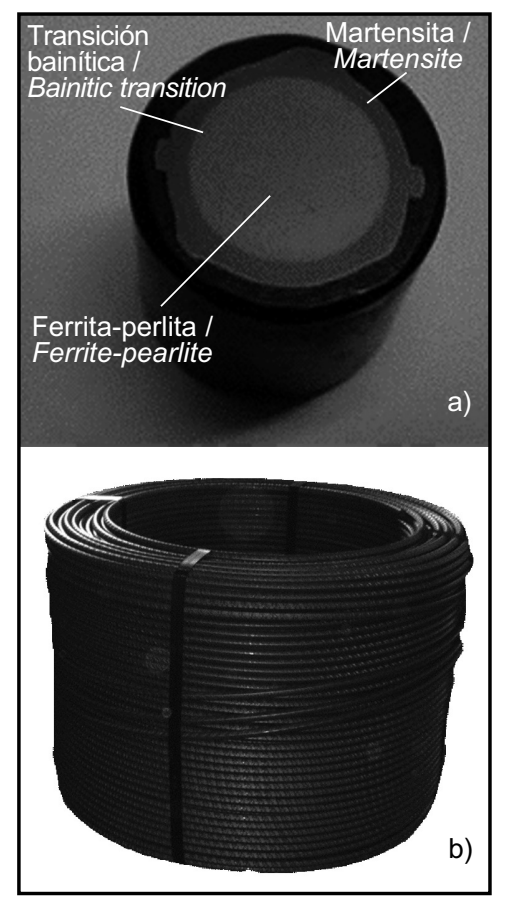

Figura 1. Preparación metalográfica de una barra de $20 \mathrm{~mm}$ que muestra los diferentes tipos de cristalización (a) y una bobina de barra de $20 \mathrm{~mm}$ de diámetro nominal (b).

Figure 1. Metallographic prepared round $20 \mathrm{~mm}$ bar showing different crystallized regions (a) and coil of $20 \mathrm{~mm}$ nominal bar diameter (b). forms whose mechanical properties are in between of the other two main materials. Figure 1 shows a metallographic preparation of a $20 \mathrm{~mm}$ round bar were the three constituting materials can be observed. By regulating the vapour pressure the thickness of the martensite crown can be varied thus controlling the strength and ductility of the complete bar. This process allows producing bars that can reach high strength and high deformations from mild steel without inclusion of expensive additions of vanadium and niobum.

After this process bars are rolled to produce a coil subjecting the bar to large strains with moderately high temperatures, Figure $1 \mathrm{~b}$. These strains are higher in the external crown where the less ductile martensite is located.

Before final use, bars are straightened in workshops in order to produce bars of the required length. This virtually eliminates the production of wastes due to cuts of bars of standard lengths. In this process, bars are bent in the opposite direction of the coil's curvature inducing very large strains in the fibres at normal temperature. Yielding of some fibres is necessary in order to produce the counter-curvature needed to obtain a straight bar.

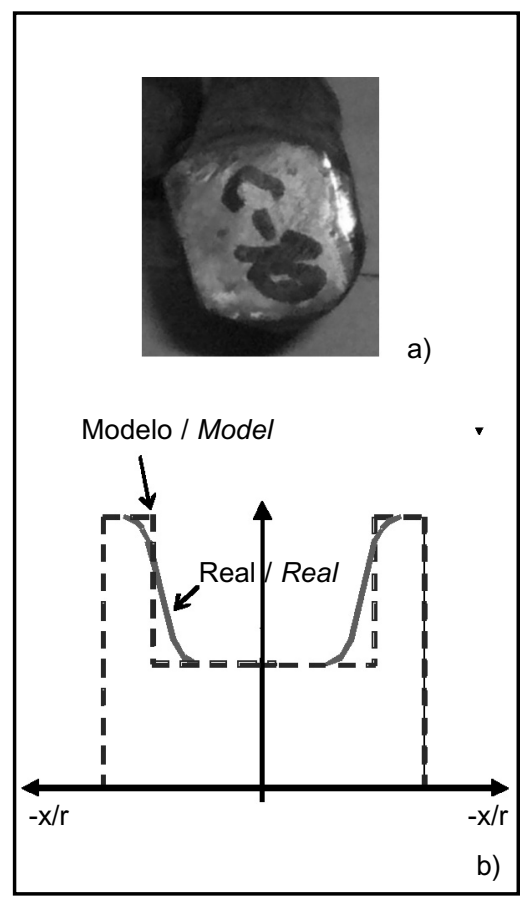

Figura 2. Sección transversal típica de barra enrollada utilizada en el estudio e idealización: a) sección transversal, b) distribución real de durezas y modelización.

Figure 2. Typical cross-section of a rolled bars used in this study and idealization: a) actual cross-section shape, b) real distribution of hardness and modelization. 
Las barras analizadas en este estudio no tenían una forma circular perfecta, de hecho la forma de la sección transversal es casi cuadrada con esquinas redondeados tal y como muestra la Figura 2. El diámetro nominal de la barra es el equivalente al del área efectiva de la sección. Esta forma permite que el rollo se embobine mejor y permite un mejor flujo de paso a través de la máquina estribadora. Además, se evita que las barras sufran torsión al ser desdobladas. La Figura 2 muestra la distribución heterogénea de las características del material utilizadas en el modelo numérico desarrollado en el estudio. En éste sólo se han considerado las regiones martensítica y ferriticoperlítica, despreciando la pequeña interfase bainítica.

\section{CARACTERIZACIÓN DEL MATERIAL}

El objetivo de esta fase del estudio es estimar las propiedades mecánicas del material virgen antes de ser sometido a ningún proceso tenso-deformacional. Más concretamente, se desea caracterizar las propiedades de los dos materiales que forman las dos zonas de la sección de la barra: corona y núcleo.

Para ello se ensayaron barras de referencia para obtener sus correspondientes curvas tensión-deformación de la barra completa compuesta por corona y núcleo. Las muestras se tomaron de barras destinadas a la producción de rollos pero antes de embobinar. Por lo tanto se trataba de barras rectas en las que no se había introducido las tensiones derivadas del enrollado y enderezado.

Paralelamente, se tomaron muestras de barras de la misma procedencia y colada que las de referencia y fueron mecanizadas según se muestra en la Figura 3. Este procedimiento eliminó la corona martensítica así como las posibles tensiones residuales existentes en esta etapa, debidas al temple y el revenido.

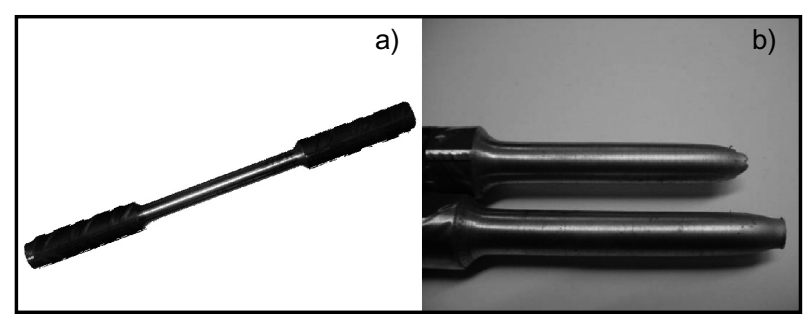

Figura 3. Mecanizado de las barras para ensayo de tracción del núcleo dúctil. a) Barra no ensayada, b) Barra ensayada. Figure 3. Mechanized bar for traction test of the ductile core. a) Before test, b) Tested bar.
The bars analysed in this study did not have a perfectly circular shape, instead the actual cross-section is almost square with rounded corners as can be seen in Figure 2. The nominal diameter of the bar is the equivalent to the effective area of the section. This particular shape allows better flow through the straightening machine avoiding torsion and locking of the coils when unrolling. Figure 2 also shows the heterogenous distribution of the material characteristics used for the numerical modelling performed in this research. In this sense, only martensite and ferrite-pearlite regions are considered while the small bainitic transition is neglected.

\section{MATERIAL CHARACTERIZATION}

The objective of this phase of the study is to estimate the mechanical properties of the virgin material before being affected - or affected as less as possible - by stresses and strains introduced by fabrication process. More precisely, it is desired to obtained the mechanical properties of the two main regions forming the bar's section: core and crown.

Reference bars were tested in order to obtain the mean stress-strain curve of the complete heterogeneous bar. Samples were taken from bars before winding of coils, so no residual stresses from bending and straightening existed.

On the other hand, bars from the same origin and melt of the reference bars were mechanized as shown in Figure 3 in order to eliminate the martensite crown. Mechanization eliminated the martensite crown as well as any residual stresses existing in this stage of fabritation. These samples were tested in tension in order to obtain the mechanical characteristics of the ferrite-pearlite core.

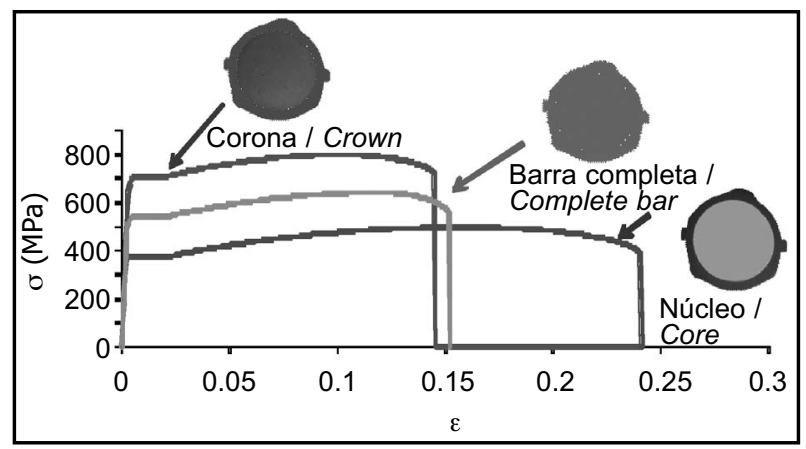

Figura 4. Curvas tensión-deformación de las diversas regiones de la sección transversal.

Figure 4. Stress-strain curves of the different regions of the cross-section. 
Las barras mecanizadas fueron ensayadas a tracción simple con lo que se obtuvieron las características mecánicas y de ductilidad del núcleo ferritico-perlítico. La profundidad de la capa de martensita así como la de la transición se pueden determinar a partir de un análisis metalográfico. Dado que se conocía el comportamiento de la barra heterogénea completa y las del material del núcleo, es posible inferir la curva tensión deformación de la corona martensítica. Las curvas tensión-deformación obtenidas son las graficadas en la Figura 4.

\section{INVESTIGACIÓN EXPERIMENTAL DE LOS EFECTOS DEL ENROLLADO Y ENDEREZADO}

\subsection{Metodología}

Se llevaron a cabo dos campañas experimentales para cuantificar los diferentes efectos introducidos en el proceso de fabricación y la influencia del enderezado. El propósito de la primera campaña era la identificación de las variaciones introducidas por el proceso de enrollado y enderezado en las curvas tensión-deformación de las barras enderezadas del diámetro máximo, comercialmente producidas con acero de alta ductilidad, de una marca con certificado de calidad. Se estudiaron un total de 90 muestras de diámetros nominales de 12,16 y 20 $\mathrm{mm}$. Todas las muestras fueron obtenidas a partir de bobinas procedentes de la misma colada; por ello, la composición química de las diversas barras puede ser considerada idéntica así como las propiedades mecánicas del material base, dentro de las variaciones estadísticas de carácter normal.

Las muestras rectas se tomaron de la cola y cabeza de cada barra, extrayéndose directamente del tren de laminación después del proceso TEMPCORE ${ }^{\circledR}$ y antes del enrollado en bobinas. Una vez fabricadas las bobinas, se extrajeron muestras de barra enrollada de tres regiones diferentes. Se midieron los radios de curvatura de cada muestra siendo cada una clasificada según lo establecido en las Tablas 2 y 3 . Estas Tablas también muestran el cociente entre el diámetro de la barra y su radio de curvatura, valor relacionado directamente con la deformación máxima existente en las fibras más exteriores.
Thickness of martensite crown as well as the transition zone can be determined from the metalografic analysis as shown in Figure 1. Since this the mean stress-strain curve of the heterogenous bar and the core were known from experimentation, it is possible to deduce the stressstrain curve of the crown. The stress-strain curves for the complete bar, crown and core are shown in Figure 4.

\section{EXPERIMENTAL RESEARCH ON THE EFFECTS OF WINDING AND STRAIGHTENING}

\subsection{Methodology}

Two experimental campaigns were carried out in order to quantify the different effects introduced in manufacture and the influence of the straightening quality. The aim of the first campaign was to characterize the variations introduced by the coiling and strengthening process on the stress-strain curve on the final straight bars of maximum diameters, being currently commercially produced with special ductility grade $(S D)$, of brand with quality certification. A total of 90 samples of nominal diameters of 12, 16 and $20 \mathrm{~mm}$ were considered in the study. All coils analysed came from the same melt; therefore, chemical composition of the different bars can be considered as the same and so the mechanical characteristics of the base material within the normal statistical variations.

Straight reference samples were taken from the head and tail of each bar directly from the lamination train after TEMPCORE ${ }^{\circledR}$ and before rolling the coils. After coils have been manufactured, samples of loops were taken from three different regions of it. Loops radiuses were measured and each sample was classified on the sets shown in Tables 2 and 3. The same Tables also show the ratio between the bar diameter and the radius of the spiral (or loop). This parameter is directly related to the maximum strains taking place in the outermost fibres.

Tabla 2 / Table 2

Muestras de bobina tomadas para $\varnothing 12 \mathrm{y} \varnothing 16$. Sampling sets for $\varnothing 12$ and $\varnothing 16$ coils.

\begin{tabular}{|c|c|c|c|c|}
\hline \multirow{2}{*}{ Zona / Set } & \multicolumn{2}{|c|}{ Radio de curvatura / Loops radius (mm) } & \multicolumn{2}{|c|}{$\varnothing / \mathbf{r}$ ratio [-] } \\
\cline { 2 - 5 } & $\varnothing=\mathbf{1 2} \mathbf{~ m m}$ & $\varnothing=16 \mathbf{~ m m}$ & $\varnothing=12 \mathbf{~ m m}$ & $\varnothing=16 \mathbf{~ m m}$ \\
\hline A: Cabeza recta / Head straight & - & - & 0 & 0 \\
\hline B: Cabeza curva / Head loop & 430 & 440 & $2.791 \mathrm{E}-2$ & $3.636 \mathrm{E}-2$ \\
\hline C: Centro curva / Centre loop & 490 & 510 & $2.449 \mathrm{E}-2$ & $3.137 \mathrm{E}-2$ \\
\hline D: Cola curva / Tail loop & 575 & 595 & $2.087 \mathrm{E}-2$ & $2.689 \mathrm{E}-2$ \\
\hline E: Cola recta / Tail straight & - & - & 0 & 0 \\
\hline
\end{tabular}


Tabla 3 / Table 3

Muestras de bobina tomadas para $\varnothing 20$.

Sampling sets for $\varnothing 20 \mathrm{~mm}$ coils.

\begin{tabular}{|c|c|c|}
\hline \multirow{2}{*}{ Zona / Set } & Radio giro / Loops radius $\mathbf{~ ( m m ) ~}$ & $\Delta / \mathbf{r}$ ratio [-] \\
\cline { 2 - 3 } & $\varnothing=\mathbf{2 0} \mathbf{~} \mathbf{m}$ & 0 \\
\hline Cabeza y cola rectas / Head and tail straight & - & $\mathbf{~ m m}$ \\
\hline N1 & 450 & $4.444 \mathrm{E}-2$ \\
\hline N2 & 465 & $4.301 \mathrm{E}-2$ \\
\hline N3 & 500 & $4.000 \mathrm{E}-2$ \\
\hline N4 & 550 & $3.636 \mathrm{E}-2$ \\
\hline N5 & 615 & $3.252 \mathrm{E}-2$ \\
\hline
\end{tabular}

La finalidad de la segunda campaña consistía en la evaluación de la sensibilidad del proceso de enderezado a situaciones propias de la práctica habitual. Con esta finalidad, se seleccionaron cinco talleres diferentes que suministraron muestras de barra enderezadas. Paralelamente se tomaron muestras para ser enderezadas en condiciones de laboratorio. Los talleres seleccionados son representativos de medianas y grandes empresas; siendo el criterio de elección su producción anual de acero. Un total de 140 muestras fueron ensayadas y analizadas en esta campaña.

\subsection{Parámetros medidos}

Todas las barras de la primera campaña así como las muestras de referencia de la segunda campaña fueron enderezadas en condiciones de laboratorio. Todos los ensayos se realizaron de acuerdo al ensayo de tracción normalizado según la normativa de referencia (1). Los parámetros medidos fueron los indicados en la Figura 5. El límite elástico $\left(f_{y}\right)$, el módulo de elasticidad $\left(E_{s}\right)$, la tensión máxima $\left(f_{\max }\right)$, la deformación para la máxima carga $\left(\varepsilon_{\max }\right)$ y la deformación última $\left(\varepsilon_{\mathrm{u}}\right)$ fueron medidas de acuerdo con la normativa. La deformación última $\left(\varepsilon_{u}\right)$ y la deformación para carga máxima $\left(\varepsilon_{\max }\right)$ se definen como la deformación para la que la barra se rompe y la deformación existente para la resistencia máxima, respectivamente. El valor de $\varepsilon_{\max }$ es un parámetro básico a nivel normativo para la definición del grado de ductilidad del acero.

Adicionalmente a las propiedades normativas anteriormente citadas, la tensión de inicio de no-linealidad $\left(\mathrm{f}_{\mathrm{nl}}\right)$, la deformación de iniciación de endurecimiento $\left(\varepsilon_{s h}\right)$ y la densidad de energía (En) fueron medidas para cada muestra. La iniciación de no-linealidad $\left(f_{n l}\right)$ fue definida para este estudio con el objeto de cuantificar el punto donde se inicia el redondeo de la zona elástica en transición hacia la meseta plástica. Este parámetro se define como el punto en que se produce una divergencia de resultados del $10 \%$ respecto a la regresión lineal de la rama elástica.
The objective of the second campaign was to evaluate the sensitivity of the straightening process to current practical operational situations. With this goal, five different workshops were selected in order to take samples of the straightened bars. At the same time, samples of un-straightened bars of the same coil were taken in order to be straightened in the control laboratory. The selected workshops are representative of medium to big companies; selection criterion was based on the total prepared steel produced per year. A total of 140 samples were tested and analysed in this campaign.

\subsection{Parameters measured}

All bars from the first campaign, as well as the reference bars of the second campaign, were straightened in laboratory conditions. All tests were performed according to standard tension test described in (1). The parameters measured were those indicated in Figure 5. Yielding stress $\left(f_{y}\right)$, modulus of elasticity $\left(E_{s}\right)$, strength $\left(f_{\max }\right)$, strain at maximum load $\left(\varepsilon_{\max }\right)$ and ultimate strain $\left(\varepsilon_{u}\right)$, were measured according to the referred standard (1). Ultimate strain $\left(\varepsilon_{u}\right)$ and strain at maximum load ( $\left.\varepsilon_{\text {max }}\right)$ are defined as the strain at which bar separation take place and the strain corresponding to the steel strength respectively. $\varepsilon_{\max }$ is the relevant parameter for normative definition of the steel ductility grade.

In addition to the abovementioned standard properties, the stress of initiation of non-linearity $\left(f_{n l}\right)$, strain hardening initiation $\left(\varepsilon_{s h}\right)$ and the energy density (En) were also measured for each sample. A point called initiation of non-linearity $\left(f_{n l}\right)$ was defined in this study in order to quantify the rounding of the yielding plateau observed in the tests. It was defined as the point for which stresses deviate in 10\% from the linear regression of the elastic branch. 


\subsection{Efectos observados en la curva tensión- deformación}

En general, todas las variables que caracterizan la curva tensión-deformación están afectadas por el proceso de fabricación de una manera u otra. Las variables más afectadas son el límite elástico $\left(\mathrm{f}_{\mathrm{y}}\right)$, la deformación en el punto de inicio del endurecimiento $\left(\varepsilon_{\mathrm{sh}}\right)$ y la deformación para carga máxima $\left(\varepsilon_{\max }\right)$. La deformación por endurecimiento empieza para un valor inferior, es decir, $\varepsilon_{\text {sh }}$ se reduce.

Se observó una curvatura de la zona final de la rama elástica para valores de tensión inferiores al límite elástico del punto de plastificación, con una transición más suave hacia el escalón de plastificación, encontrándose esta transición caracterizada por $\mathrm{f}_{\mathrm{nl}}$. Este hecho refleja que el punto de plastificación no es uniforme en todas las fibras de la sección existiendo algunos puntos plastificados para tensiones inferiores, por efecto de la existencia de tensiones residuales, como se muestra posteriormente.

Además, el límite elástico, que en la normativa se define como la tensión asociada a una deformación residual de 0,002 , tiende a incrementarse con el proceso de fabricación. En general, el parámetro que más influencia tiene en las variaciones observadas es el cociente entre el diámetro de la barra y el radio de curvatura de la espira en la bobina ( $\varnothing / R)$.

\section{MODELO NUMÉRICO}

\subsection{Modelo del material}

Se ha desarrollado un modelo numérico de análisis no lineal para reproducir el comportamiento genérico de una barra de sección heterogénea. La geometría y

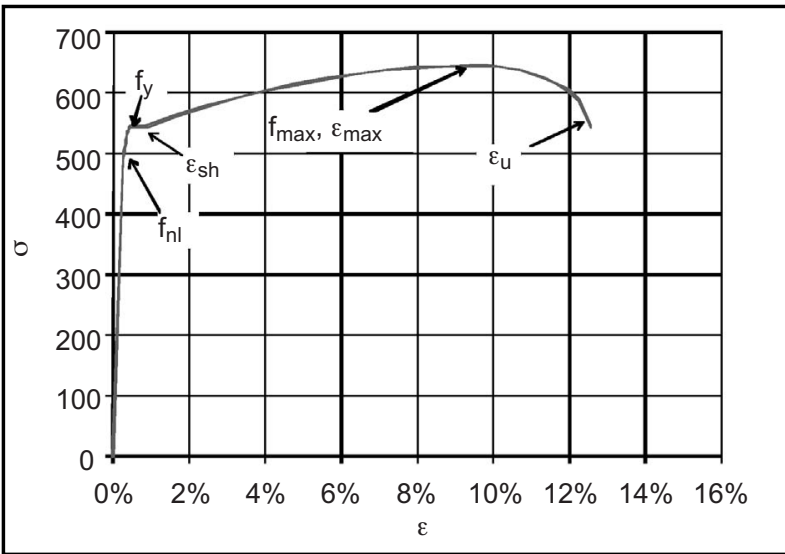

Figura 5. Definición de los parámetros medidos en la campaña experimental.

Figure 5. Definition of the parameters measured in the experimental campaign.

\subsection{Observed effects on stress-strain curves}

In general, all characteristic variables of the stress-strain curves are affected by the process in some extend. The more affected variables are the yielding stress $\left(f_{y}\right)$, the strain hardening initiation point $\left(\varepsilon_{s h}\right)$ and the strain at maximum load $\left(\varepsilon_{\text {max }}\right)$. Strain hardening starts at a lower value, i.e. $\varepsilon_{\text {sh }}$ is reduced.

A non-linear curvature was observed before yielding stress and a softener transition to the yield plateau, characterized by $f_{n l}$, was observed. This reflects the fact that the yielding point is not uniform in all fibres of the section but some points yield at lower stress than others due to the residual stresses distribution, as will be shown bellow.

Moreover, the nominal definition of the bar's yielding, i.e. the stress corresponding to a residual plastic strain of 0.002 , tends to increase after the process. In general, the more influencing parameter of the process is the ratio of bar's diameter to the spiral radius $(\varnothing / R)$.

\section{NUMERICAL MODEL}

\subsection{Material modelling}

A non-linear model was developed in order to reproduce the behaviour of a heterogenous bar. Actual geometry and distribution of materials properties described in

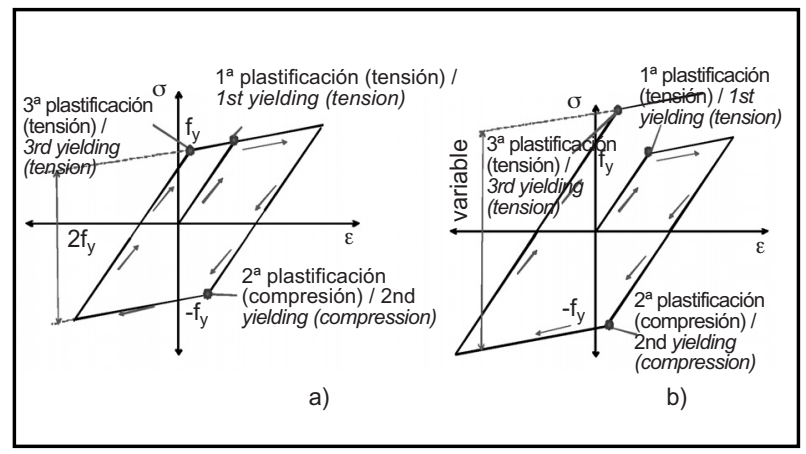

Figura 6. Diagramas cíclicos tensión-deformación con hipótesis de endurecimiento bajo cargas de tipo cíclico. a) Cinemático. b) Isótropo.

Figure 6. Typical cyclic stress-strain response under basic hardening hypotheses. a) Kinematical. b) Isotropic. 
heterogeneidad descritas en la Figura 2 fueron correctamente simuladas por elementos tipo viga con una sección compuesta por fibras.

En el modelo numérico, el comportamiento ante ciclos alternos de carga y descarga viene definido mediante la ley de endurecimiento. Tradicionalmente, existen dos tipos de endurecimientos básicos: endurecimiento cinemático e isótropo. Ambos se representan esquemáticamente en la Figura 6.

En el endurecimiento cinemático, el endurecimiento conseguido tras la platificación en una sentido de carga (p.e. tracción) produce una reducción de la tensión de plastificación cuando el sentido de la carga se alterna (p.e. se carga en compresión). De esta forma, el rango elástico total en tracción y compresión está siempre acotado una distancia igual a $2 \mathrm{f}_{\mathrm{y}}$.

Por otro lado, al plastificar con endurecimiento isótropo, el límite elástico cuando la carga cambia de sentido (p.e. de tracción a compresión) aumenta en la misma proporción que en la primera plastificación. De esta forma, el rango elástico total va aumentando con el número de ciclos.

En general, un metal puede tener ambos tipos de endurecimiento, salvo que según la aplicación concreta tiene más o menos relevancia el fenómeno producido por cada uno de ellos. El modelo constitutivo considerado en este estudio tiene un endurecimiento mixto que puede representar ambos comportamientos así como situaciones intermedias. El modelo se describe a continuación.

\subsubsection{Bases del modelo constitutivo}

La deformación total del material se considera compuesta por una deformación mecánica (dependiente del estado tensional) y una deformación no-mecánica (independiente del estado tensional) [1].
Figure 2 can be considered by means of beam elements with fiber cross-sections.

The behaviour under large cyclic stress-strain load histories is controlled by means of material's hardening rules. Two classical hardening models exist in literature: kinematic and isotropic hardening. The typical response against these models are schematically represented in Figure 6.

With kinematic models, strain hardening in a given load direction (e.g. tension) produce a reduction in yielding stress on the opposite direction (compression). In this way, the complete elastic range is always bounded to $2 f_{y}$ independently of the number of cycles or strain level.

On the other hand, hardening with an isotropic model produce and increment on the yielding stress in the opposite direction of the same magnitude of the increment of stress achieved. In this way, total elastic range increases with the number of cycles producing involving yielding and the strain level.

Actual behavior of metals is not perfectly captured by neither classical models in all stages; however, in some applications one of the two classical hypotheses is more suitable than the other. The problem dealt in this study involve stress-strains of very different magnitudes under cycle loading, therefore a mixed-hardening model has been developed. The model is described in the following.

\subsubsection{Basis of the constitutive model}

The total material strain is considered to be composed of a mechanical strain (dependent of the applied stress) and a non-mechanical strain (independent of the applied stress) [1].

$$
\varepsilon^{t o t}=\varepsilon^{m}+\varepsilon^{n m}
$$

En este caso de estudio, la única deformación no-mecánica considerada es la debida a la temperatura $\left(\varepsilon_{\mathrm{T}}\right)$ [2].

In this case study, the only non-mechanical strain that is considered is the strain increment produce by temperature changes $\left(\varepsilon_{T}\right)$ [2].

$$
\varepsilon^{n m}=\varepsilon_{T}(T)
$$

Para simplificar la notación, en lo sucesivo se denominará $\varepsilon$ a la deformación mecánica [3]:

In the following, in order to simplify the notation, the mechanical strain will be denoted as $\varepsilon$ [3]:

$$
\varepsilon^{m}=\varepsilon=\varepsilon^{t o t}-\varepsilon^{n m}
$$

Adicionalmente, la deformación mecánica se considera compuesta por una deformación elástica $\left(\varepsilon_{\mathrm{e}}\right)$ recuperable tras la descarga y de una deformación plástica remanente $\left(\varepsilon_{\mathrm{p}}\right)$.
Moreover, the mechanical strain is considered composed of an elastic strain $\left(\varepsilon_{e}\right)$ which is recoverable after unloading and a plastic strain $\left(\varepsilon_{p}\right)$. 
Efecto del enrollado y enderezado en las propiedades mecánicas de barras de acero de diámetro medio y grande fabricadas en rollo Effects of winding and straightening of medium and large diameter reinforcing bars manufactured in coils in their mechanical properties

Los parámetros usados para definir el material son los siguientes:

$\mathrm{f}_{\mathrm{y}}$ : Límite elástico.

$f_{\text {max }}$ : Tensión máxima.

$\mathrm{E}_{\mathrm{s}}$ : Módulo de elasticidad.

$E_{1}$ : Módulo plástico de la meseta de plastificación.

$\varepsilon_{\text {sh }}$ : Deformación en la que se inicia la fase de endurecimiento por deformación.

$\varepsilon_{\text {max }}:$ Deformación bajo tensión máxima, define el inicio de la fase de reblandecimiento.

$\varepsilon_{\mathrm{r}}$ : Deformación de rotura.

$\beta$ : Parámetro de endurecimiento mixto.

\subsubsection{Curva $\sigma-\varepsilon$ envolvente}

La envolvente monotónica de la curva tensión-deformación, $\sigma_{e n v}(\varepsilon)$, se definen en la ecuación [4] y se muestra en la Figura 7. La misma consta de 4 fases: rama elástica, meseta de plastificación, endurecimiento y reblandecimiento.

Rama elástica $\left(\varepsilon \leq f_{y} / E_{s}\right)[4.1]$
The model parameters are the following:

$f_{y}:$ Yielding stress

$f_{\text {max }}:$ Maximum stress

$E_{S}:$ Modulus of elasticity

$E_{1}$ : Plastic modulus of the yielding plateau

$\varepsilon_{\text {sh: }}$ Strain initiating the strain hardening phase.

$\varepsilon_{\text {max }}:$ Strain at maximum stress, also defines strain softening phase.

$\varepsilon_{r}:$ Ultimate strain

ß: Mixed-hardening parameter.

\subsection{2. $\sigma-\varepsilon$ envelope curve}

The envelope $\sigma$ - $\varepsilon$ curve, $\sigma_{\text {env }}(\varepsilon)$, is defined in ec. [4] and represented in Figure 7. This curve comprises 4 phases: elastic branch, yielding plateau, strain hardening and strain softening.

Elastic branch $\left(\varepsilon \leq f_{y} / E_{s}\right)[4.1]$

$$
\sigma_{e n v}=E_{s} \varepsilon
$$

Meseta de plastificación $\left(f_{y} / E_{S}<\varepsilon \leq \varepsilon_{s h}\right)$ [4.2]

Yielding plateau $\left(f_{y} / E_{s}<\varepsilon \leq \varepsilon_{s h}\right)[4.2]$

$$
\sigma_{e n v}=f_{y}+E_{1}\left(\varepsilon-\frac{f_{y}}{E_{s}}\right)
$$

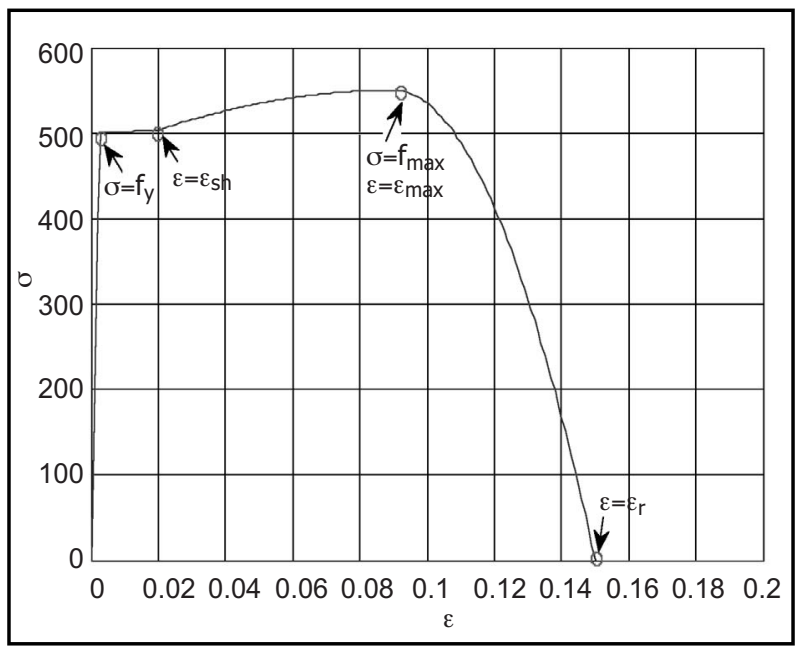

Figura 7. Envolvente de la curva tensión-deformación del modelo.

Figure 7. Stress-strain envelope curve of the model. 


$$
\sigma_{e n v}=f_{s h}-\left(f_{\max }-f_{s h}\right)\left[\frac{\varepsilon-\varepsilon_{s h}}{\varepsilon_{\max }-\varepsilon_{s h}}\left(\frac{\varepsilon-\varepsilon_{s h}}{\varepsilon_{\max }-\varepsilon_{s h}}-2\right)\right]
$$

Donde:

Where:

$$
f_{s h}=f_{y}+E_{1}\left(\varepsilon_{s h}-\frac{f_{y}}{E_{s}}\right)
$$

Rama de reblandecimiento hasta la rotura $\left(\varepsilon_{\max }<\varepsilon \leq \varepsilon_{u}\right)[4.4] \quad$ Softening branch $\left(\varepsilon_{\max }<\varepsilon \leq \varepsilon_{u}\right)[4.4]$

$$
\sigma_{e n v}=f_{\max }\left[2\left(1-\frac{\varepsilon-\varepsilon_{\max }}{\varepsilon_{u}-\varepsilon_{\max }}\right)-\left(1-\frac{\varepsilon-\varepsilon_{\max }}{\varepsilon_{u}-\varepsilon_{\max }}\right)^{2}\right]
$$

\subsubsection{Evaluación del estado tensional}

La respuesta ante cargas y descargas reversibles se controla mediante un modelo de endurecimiento mixto que dispone de un parámetro $(\beta)$ para controlar el tipo de comportamiento. $\beta$ varía entre 0 y 1 , en los valores extremos reproduce el comportamiento cíclico totalmente cinemático $(\beta=0)$ o el totalmente isótropo $(\beta=1)$. Asignando valores intermedios, se obtiene un comportamiento mixto.

El modelo tiene dos variables de estado: deformación plástica $\left(\varepsilon_{p}\right)$ y el potencial plástico $(\alpha)$ cuyos valores iniciales en el material virgen son cero en ambos casos.

La evaluación del estado del material ante una determinada deformación requiere conocer los valores previos de las variables de estado, las cuales se actualizan al final de cada paso de carga. Los pasos generales se describen a continuación:

1. Cálculo de la deformación mecánica [5]:

\subsubsection{State evaluation}

Response against cyclic loading is controlled by means of a mixed-hardening model characterized by a material parameter $(\beta)$ ranging between 0 and 1 . For $\beta=0$ a pure kinematic hardening behaviour is reproduced, while for $\beta=1$ the behaviour is pure isotropic. Values between 0 and 1 produce mixed hardening response.

The model has two state variables: plastic strain $\left(\varepsilon_{p}\right)$ and plastic potential $(\alpha)$ whose initial values in the virgin material are zero in both cases.

Evaluation of the material stress state in a load step requires knowing the previous values of the two state variables, which are subsequently updated at the end of the load step. This is done as described in the following steps:

\section{Computation of mechanical strain [5]:}

$$
\varepsilon=\varepsilon^{t o t}-\varepsilon^{n m}
$$

2. Estimación de la deformación elástica [6]:

2. Estimation of trial elastic strain [6]:

$$
\varepsilon_{e}=\varepsilon-\varepsilon_{p, o l d}
$$

3. Cálculo de la tensión con la hipótesis de comportamiento elástico [7]:

3. Computation of elastic stress [7]:

$$
\sigma_{e}=E_{s} \varepsilon_{e}
$$

4. Cálculo de la tensión de plastificación para el estado actual. Esta tensión se obtiene a partir de la curva envolvente, Ec. [4], y del tipo de endurecimiento considerado. A continuación se presenta un procedimiento general
4. Computation of plastic stress for the actual state. This stress is computed from the $\sigma-\varepsilon$ envelope considering the type of hardening and the load history recorded in the state variables. In the following, a procedure is 
Efecto del enrollado y enderezado en las propiedades mecánicas de barras de acero de diámetro medio y grande fabricadas en rollo Effects of winding and straightening of medium and large diameter reinforcing bars manufactured in coils in their mechanical properties

para un endurecimiento mixto caracterizado por el parámetro $\beta$ :

4.1 Tensión ficticia para comportamiento isótropo [8, 9]: presented for the case of mixed hardening characterized by the material parameter $\beta$ :

$$
\begin{aligned}
& \varepsilon_{i}^{*}=\left|\varepsilon_{e}\right|+\alpha_{o l d} \\
& \sigma_{i}^{*}=\sigma_{e n v}\left(\varepsilon_{i}^{*}\right)
\end{aligned}
$$

4.2 Tensión ficticia para comportamiento cinemático [10, 11]: $\quad 4.2$ Fictitious kinematic stress [10, 11]:

$$
\begin{aligned}
& \varepsilon_{k}^{*}=\left|\varepsilon_{e}\right|+\left|\varepsilon_{p}\right| \\
& \sigma_{k}^{*}=\sigma_{e n v}\left(\varepsilon_{k}^{*}\right)
\end{aligned}
$$

4.3 Tensión de plastificación mixta [12]:

4.3 Plastic stress with mixed-hardening [12]:

$$
\sigma_{y}=\beta \operatorname{sign}\left(\varepsilon_{e}\right) \sigma_{i}^{*}+(1-\beta)\left[\operatorname{sign}\left(\varepsilon_{e}\right) f_{y}+\operatorname{sign}\left(\varepsilon_{p, o l d}\right)\left(\sigma_{i}^{*}-f_{y}\right)\right]
$$

5. Determinar si el acero está en rango plástico o elástico [13]: $\quad$ 5. Determine if material is in the plastic or elastic range [13]:

$$
\begin{aligned}
& \text { Sí / if }\left|\sigma_{e}\right|>\left|\sigma_{y}\right| \rightarrow \text { Rango plástico / Plastic range } \\
& \text { Sí / if }\left|\sigma_{e}\right| \leq\left|\sigma_{y}\right| \rightarrow \text { Rango elástico / Elastic range }
\end{aligned}
$$
6. Calcular estado del material
6. Compute material stress and update state

6.1 Si se está en rango plástico (Ec. [13] es verdadera) [14, 6.1 If material is in plastic range (Eq. [13.1] is true) [14, 15, 15, 16]: 16]:

$$
\begin{gathered}
\sigma=\sigma_{y} \\
\varepsilon_{p, \text { new }}=\varepsilon-\frac{\sigma_{y}}{E_{s}} \\
\alpha_{\text {new }}=\alpha_{\text {old }}+\left|\varepsilon_{p, \text { new }}-\varepsilon_{p, \text { old }}\right|
\end{gathered}
$$

6.2 Si se está en rango elástico (Ec. [13] es verdadera) 6.2 If material is in the elastic range (Eq. [13.b] is true) $[17,18,19]$ : $[17,18,19]$ :

$$
\begin{gathered}
\sigma=\sigma_{e} \\
\varepsilon_{p, \text { new }}=\varepsilon_{p, \text { old }} \\
\alpha_{\text {new }}=\alpha_{\text {old }}
\end{gathered}
$$

En la Figura 8 se muestra la respuesta del modelo ante cuatro valores distintos del parámetro de endurecimiento $\beta$.
Figure 8 shows the cyclic response of the model for four different values of the mixed-hardening parameter $\beta$ 
El tipo de endurecimiento tiene dos efectos en la respuesta cíclica de una fibra de acero. Por un lado, puede observarse que a medida que el factor $\beta$ toma valores mayores el nivel la tensión plástica va aumentando progresivamente. En el caso de endurecimiento cinemático, los ciclos de carga pueden mantenerse indefinidamente mientras la deformación mecánica total no alcance la deformación de rotura de la curva envolvente.

Por otro lado, en el comportamiento mixto $(\beta>0)$ el material puede alcanzar la rotura aunque se encuentra a niveles de deformaciones inferiores a $\varepsilon_{\max }$. Esto se consigue a través del potencial plástico $(\alpha)$ que no es recuperable con los ciclos de carga e introducen cierta memoria de la historia de carga previa. De este modo, puede observarse en las Figuras 8.c y 8.d que la curva se torna no-lineal al alcanzar los niveles de tensión propios de la zona de endurecimiento por deformación o incluso puede alcanzarse la zona de reblandecimiento tras varios ciclos de carga $y$, eventualmente la rotura. Por lo tanto, la pérdida de ductilidad de una fibra tras sufrir una historia de carga cíclica estará controlada por el parámetro $\beta$. where the effects of the type of hardening can be noticed. On one hand, increasing the value of $\beta$ progressively increases the yielding stress after different cycles. In the case of kinematic hardening $(\beta=0)$, cyclic loading can be indefinitely applied as long as the total strain does not reach rupture strain in the envelope curve.

On the other hand, a mixed-hardening with $\beta>0$ can reproduce failure after a large number of cycles even if the total strain if way bellow $\varepsilon_{\text {max }}$. This is achieved be means of the potential plastic variable $(\alpha)$ which is unrecoverable after load reversal and introduces certain memory of the previous load history. In this way, it can be observed in Figs. 8.C and 8.d that the cyclic curve turns non-linear when the stress levels of the strainhardening phase are reached; eventually, even strain softening can take place. Therefore, ductility loss in a certain fibre after a certain load history can be controlled by parameter $\beta$.

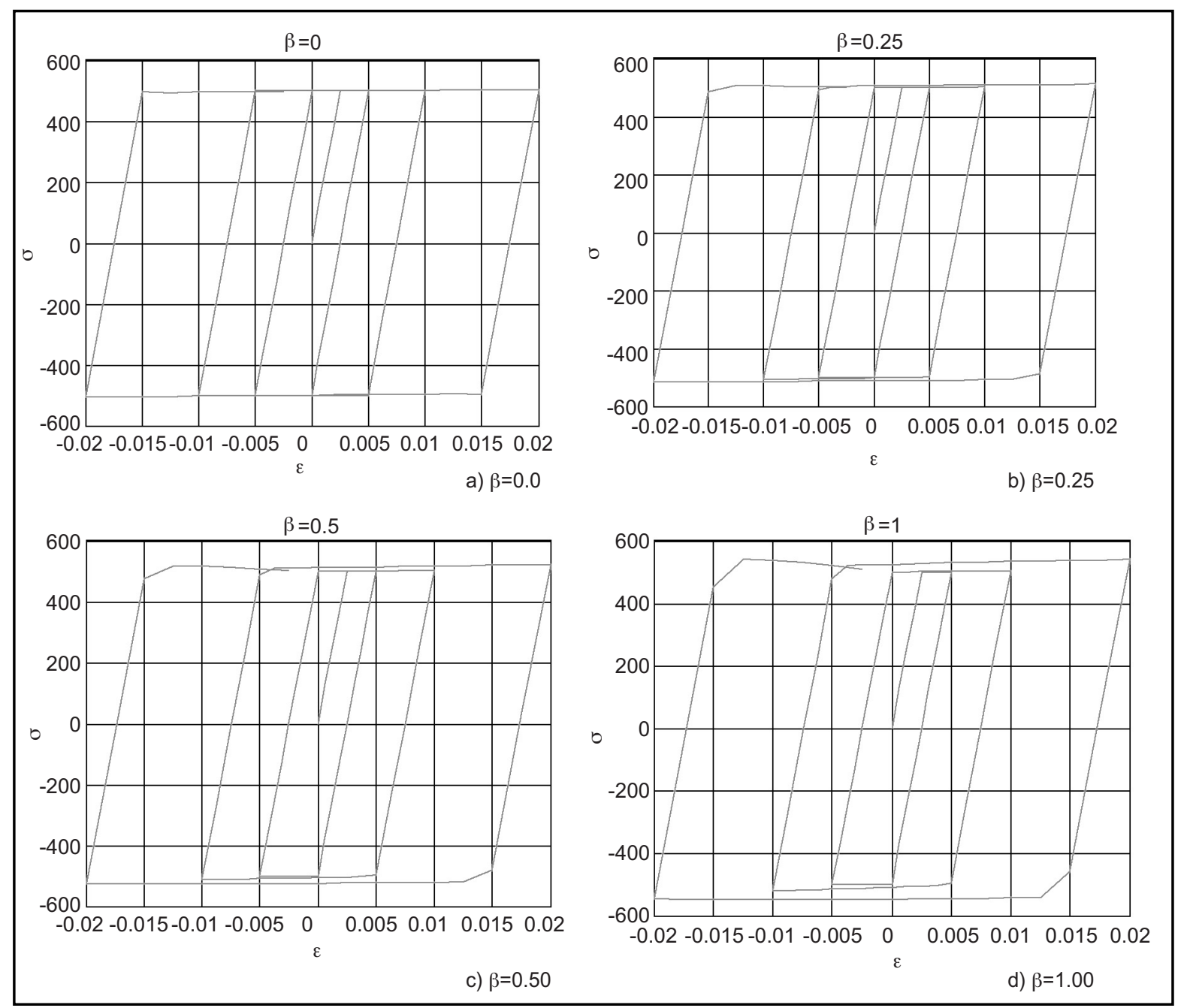

Figura 8. Efectos del tipo de endurecimiento en la respuesta cíclica.

Figure 8. Effects of the type of hardening in the cyclic response. 


\subsubsection{Efectos de altas temperaturas}

Los efectos de la temperatura se han considerado mediante funciones específicas que modifican las propiedades básicas del material en función de la temperatura. Los parámetros de modificación KY, KU y KE se definen a partir del límite elástico, resistencia del acero y el módulo de elasticidad. Los parámetros de modificación se ajustan a partir de información experimental mediante tramos rectos. Las Figuras 9, 10 y 11 muestran la diferencia entre la función empleada y los resultados experimentales extraídos de fuentes bibliográficas. En la referencia (7) se puede encontrar una revisión literaria y comparación de diferentes resultados experimentales relativos a la influencia de la temperatura en las propiedades mecánicas mencionadas.

El coeficiente de dilatación térmica del acero presenta un comportamiento no-lineal para temperaturas superiores a $100{ }^{\circ} \mathrm{C}$. Esto se ha tenido en cuenta en el modelo mediante la curva de deformación térmica-temperatura que se representa en la Figura 12 y viene definida en la referencia (8).

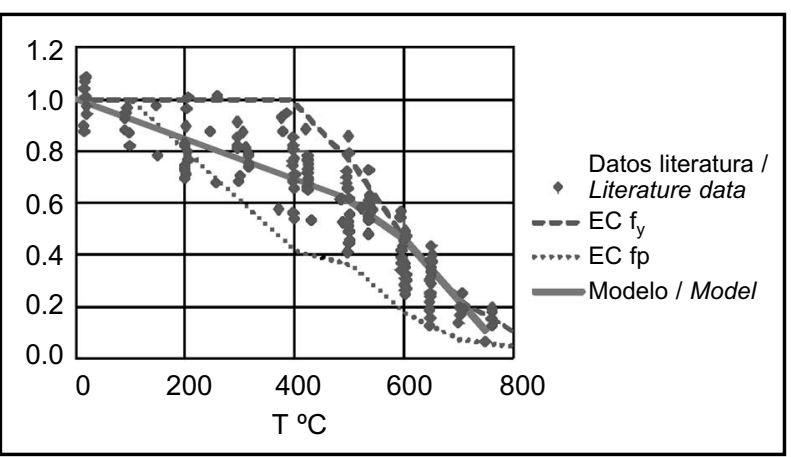

Figura 9. Variación de la $\mathrm{f}_{\mathrm{y}}$ con la temperatura.

Figure 9. Variation of the yielding stress $f_{y}$ with temperature.

\subsubsection{Effects of high temperature}

The effects of high temperature are taken into account by means of specific functions that modify the basic material properties in terms of temperature. Modification functions $K Y, K U$ and $K E$ are referred to yielding stress, strength and elastic modulus. These parameters are adjusted after experimental information using stepwise linear curves. Figs. 9, 10 and 11 show the difference between the functions used in the model and the observation available in literature. A review and comparison of the effects of high temperature on steel properties can be found in reference (7).

Thermal expansion shows a non-linear relationship with temperature after $100{ }^{\circ} \mathrm{C}$. This is considered in the model by means of the curve presented in Figure 12 which is defined in reference (8).

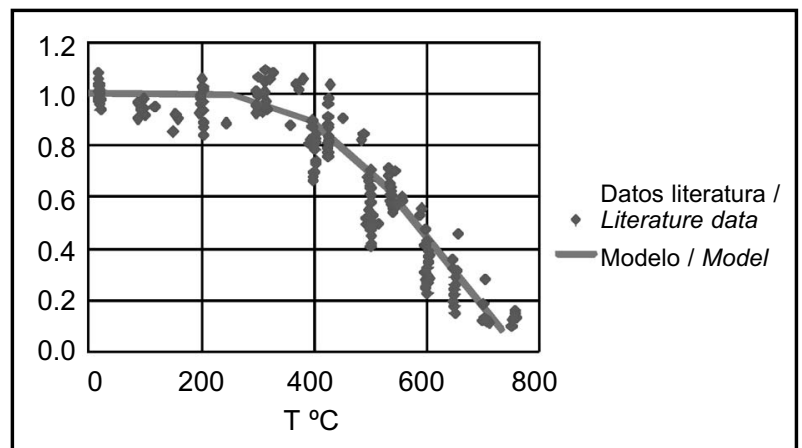

Figura 10. Variación de la $\mathrm{f}_{\max }$ con la temperatura. Figure 10. Variation of the strength $f_{\max }$ with temperature.

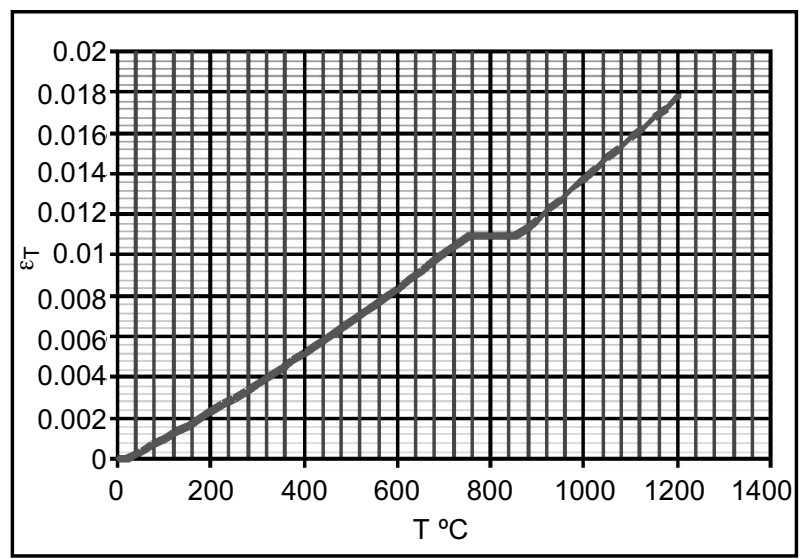

Figura 12. Expansión térmica $\left(\varepsilon_{T}\right)$ para diferentes temperaturas. Figure 12. Thermal expansion $\left(\varepsilon_{T}\right)$ for different temperatures.
Figura 11. Variación del modulo de Young con la temperatura. Figure 11. Variation of Young modulus with temperature.

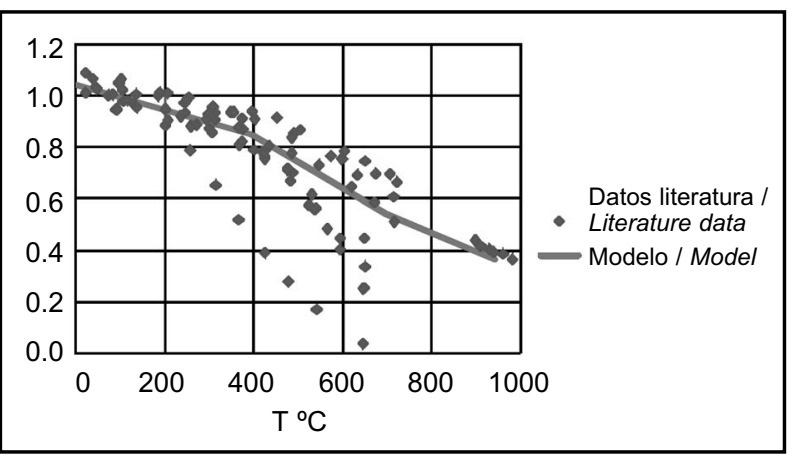




\subsection{Modelización seccional}

La geometría real de la sección de la barra y la heterogeneidad de la distribución de los materiales de la corona y el núcleo se tienen en cuenta en la respuesta seccional de la misma mediante la estrategia de discretización mediante fibras. Esta técnica se basa en las hipótesis de Navier-Barnoulli que relacionan la distribución de deformaciones en cada punto de la sección transversal con la elongación y curvatura de la barra. La integración de los esfuerzos resistidos se lleva a cabo mediante técnicas de diferencias finitas en la que cada punto de integración, denominado fibra, se caracteriza por una área tributaria, su posición y un material constituyente. En las referencias $(9,10)$, entre otras, pueden encontrarse una explicación exhaustiva sobre las bases del tipo de modelo seccional.

Este método de análisis permite además considerar los efectos de la distribución térmica durante las diferentes fases del proceso de doblado y desdoblado.

\subsection{Calibración del tipo de endurecimiento}

El tipo de endurecimiento considerado tiene una gran influencia en la respuesta bajo altas deformaciones de tipo cíclico como se ve en la Figura 8 a nivel de una fibra. En la Figura 13 se muestra una simulación de un ensayo de tracción de una barra de $20 \mathrm{~mm}$ de diámetro que ha sido sometida a un proceso de doblado y enderezado con un radio de espira de $450 \mathrm{~mm}$. En la curva se muestran las diferentes tipos de curvas que se pueden obtener para diferentes tipos de endurecimiento y se comparan con las de la fibra virgen.

El parámetro $\beta$ de endurecimiento mixto fue calibrado con la información experimental de la campaña descrita en el apartado 4. En vista de que la variable más afectada por el proceso de doblado y enderezado es la ductilidad de la barra, caracterizada por el valor de $\varepsilon_{\max }$, se realizó un ajuste de mínimos cuadrados de la pérdida de ductilidad observada experimentalmente. Se definió así un valor de $\beta=0,07$ para el tipo de barras analizadas.

\section{ESTUDIO NUMÉRICO}

En este apartado se describe y desarrolla la simulación numérica del proceso de fabricación y enderezado. El objetivo del apartado es identificar los diversos fenómenos no-lineales producidos durante el proceso completo de embobinado, enderezado y posterior ensayo a tracción. La simulación descrita a continuación se lleva a cabo sobre una barra de referencia de $20 \mathrm{~mm}$ de diámetro nominal y doblada para formar una espira de radio de curvatura $400 \mathrm{~mm}(\varnothing / \mathrm{R}=0,05)$.

\subsection{Cross-section modelling}

Actual geometry of the bar's cross-section and the distribution of materials properties are considered in the sectional response by means of fibre discretization and integration. This technique is based on the hypothesis of Navier-Bernoulli that relates the distribution of strains in each point of the cross-section with the bar's elongation and curvature. The integration of internal forces is then carried out by finite-differences method in which each integration point is characterized by a fibre with a tributary area and a constitutive material. References (9, 10), among others, include an extended explanation of the basis of this sectional model and its implementation.

This analysis model also allows considering the effects of thermal distribution during the different stages of the fabrication process, bending and straightening.

\subsection{Calibration of the type of hardening}

The type of hardening considered has a big influence in the cyclic response under large strains as can be seen in Figure 8 for a single fibre. The influence of type of hardening on the complete bars can be seen in Figure 13 which shows the simulation of a tension test of a $20 \mathrm{~mm}$ bar previously bent to a spiral of $450 \mathrm{~mm}$ of radius and subsequently straightened. The simulation has been conducted with different values of the mixed-hardening parameter $(\beta)$ and compared against the virgin fibre.

Parameter $\beta$ was calibrated against the experimental data of campaign described in section 4. Since the main affected variable in the bending-straightening process is the bar's ductility, characterized by the value of $\varepsilon_{\max }$, calibration consisted on a least-squares fitting of the value of $\beta$. $A$ value of $\beta=0.07$ resulted as the best fit for the bars analyzed.

\section{NUMERICAL STUDY}

In this section the numerical simulation of the manufacturing and straightening processes is carried out using the constitutive model described above. The objective of this section is to identify the different non-linear phenomena taking place in the bar during the complete winding process, straightening and a subsequent tensile test. The analysis described in the following will be performed on a reference bar of nominal diameter $20 \mathrm{~mm}$ and bended to form a spiral with a radius of curvature of $R=400 \mathrm{~mm}(\varnothing / R=0.05)$. 


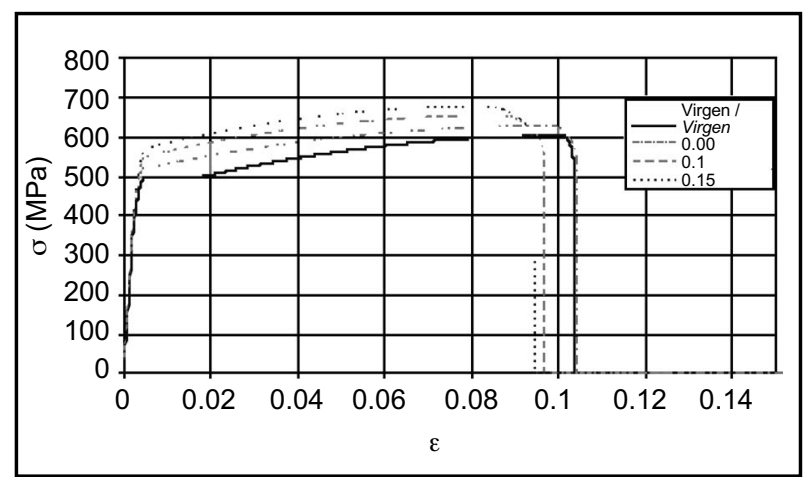

Figura 13. Efecto del parámetro de endurecimento mixto $(\beta)$ en la curva tensión-deformación de una barra enrollada de

$20 \mathrm{~mm}$ con un radio de curvatura de $450 \mathrm{~mm}$ una vez enderezada.

Figure 13. Effect of mixed hardening parameter $(\beta)$ on the stress-strain curve of a $20 \mathrm{~mm}$ bar from a $450 \mathrm{~mm}$ loop after straightening.

El proceso comienza con el enrollado de la barra en la bobina. En esta fase existe un gradiente térmico entre el núcleo y la corona exterior por efecto del temple severo y posterior revenido; generalmente, la temperatura del núcleo se encuentra a $800{ }^{\circ} \mathrm{C}$ mientras en la superficie los valores son de alrededor de $400{ }^{\circ} \mathrm{C}$. Las altas temperaturas producen tensiones autoequilibradas además de reducir el límite y módulo de elasticidad de cada punto de la barra como se muestra en las Figuras 9 y 11. La Figura 14 muestra la distribución de tensiones justo después del doblado, se observa la plastificación generalizada en diferentes puntos del núcleo y la corona.

Después del doblado, las barras se enfrían a temperatura ambiente. Esta fase produce tensiones auto equilibradas como las descritas en la Figura 15 para el caso más simple de la barra recta. Al ser la temperatura superior en el núcleo que en la corona de martensita, Figura 16.a, las deformaciones de contracción son mayores en la capa exterior si se dejan deformar las fibras libremente. La compatibilidad de deformaciones debe garantizarse entre las diversas fibras de la barras; por ello, se producen tensiones de tracción por compatibilidad. Éstas son mayores en el núcleo que en la corona exterior tal y como se muestra en la Figura 15.b. Finalmente, para restablecer el equilibrio entre fibras, se introduce una tensión de compresión sobre toda la sección (Figura 16.c). La distribución final de tensiones es la representada en la Figura 15.d.

Para el caso de barra enrollada, la distribución final de tensiones después del enfriamiento se muestra en la Figura 16. Se puede observar cómo el núcleo presenta unas tensiones residuales que implican la plastificación de la zona. Sin embargo, la corona presenta una distribución no-uniforme sólo plastificando la zona cóncava de la barra, encontrándose la parte convexa con un estado tensional mucho más bajo.

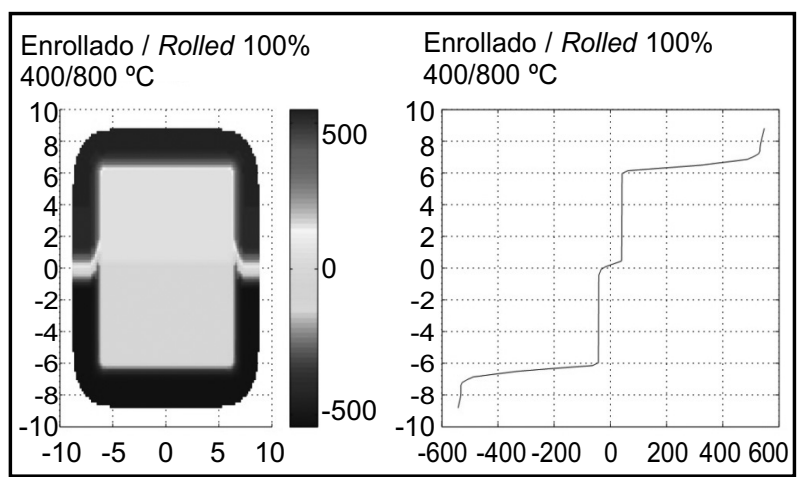

Figura 14. Distribución de tensiones en la barra después del enrollado a $400^{\circ} \mathrm{C}$. Contorno de la sección transversal y distribución de tensiones en el plano medio.

Figure 14. Stress distribution on bar after bending at $400{ }^{\circ} \mathrm{C}$ external temperature. Cross-section contour and middle plane distribution.

The process starts with the winding of the bar to form the coil. At this stage, a temperature gradient between the core and the exterior perimeter exists, due to the severe tempering and subsequent reheating; typically, the core temperature is around $800^{\circ} \mathrm{C}$ while on the surface temperature is closed to $400^{\circ} \mathrm{C}$. These high temperatures produce self-balanced thermal stresses and affect the yielding stress and modulus of elasticity as shown in Figs. 9 and 11. Figure 14 shows the distribution of stresses during the bending process. It is evident the extended yielding on different points of the crown and core.

After bending, the bar cools down to environmental temperature producing additional self-balanced stresses as described in Figure 15 for the simpler case of a noncurved bar. Since the initial temperature is higher in the internal core than in the martensite crown, Figure 15a, it results that after cooling free temperature contraction strains tends to be higher in the crown. However, compatibility has to be maintained among bar's fibres; therefore, tensile stresses take place. These are also higher in the core than in the crown as sketched in Figure $15 b$. Finally, in order to re-establish equilibrium, uniform compression stresses take place in the section (Figure 15.c). The final stress distribution after cooling is as represented in Figure $15 d$.

For the case of the curved bar, the final stress distribution after cooling is shown in Figure 16. It can be seen that the core has tensile residual stresses implying yielding of this region. However, crown has non-uniform compression stresses only yielded in the concave side of the bar, convex side is also in compression but the stresses are lower. 


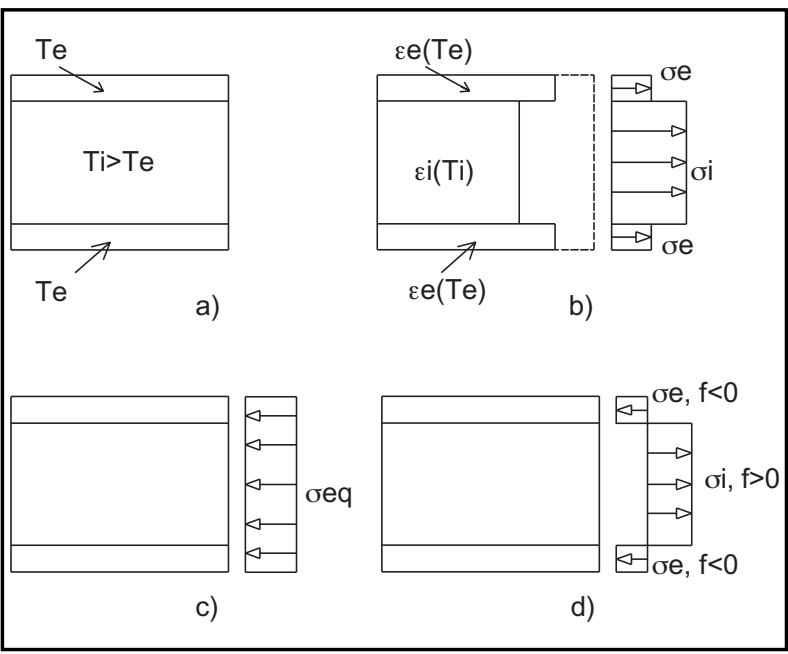

Figura 15. Estado auto equilibrado de tensiones después del enfriamiento de la barra: a) distribución a temperatura inicial, b) deformaciones térmicas libres y deformaciones por compatibilidad después del enfriamiento, c) tensiones por restitución del equilibrio, d) distribución final.

Figure 15. Self-balanced stresses due to bar cooling: a) initial temperature distribution, b) free thermal strains and compatibility stresses after cooling, c) equilibrium stresses, d) final stress distribution.

El enderezado de las barras implica aplicar una curvatura opuesta que supone la plastificación en la cara contraria tal y como se indica en la Figura 17. La distribución de tensiones final obtenida al liberar la barra se muestra en la Figura 18. El proceso completo implica la aparición de tensiones residuales relativamente altas; los valores de éstas en el núcleo ferrítico-perlítico son del orden de $350 \mathrm{MPa}$, mientras que en la corona martensítica exterior son de $200 \mathrm{MPa}$. Cabe resaltar que a diferencia de la distribución de tensiones propia de una barra recta sometida a un proceso TEMPCORE ${ }^{\circledR}$, en la que se produce una distribución de tensiones uniformes de compresión en la corona y de tracción en el

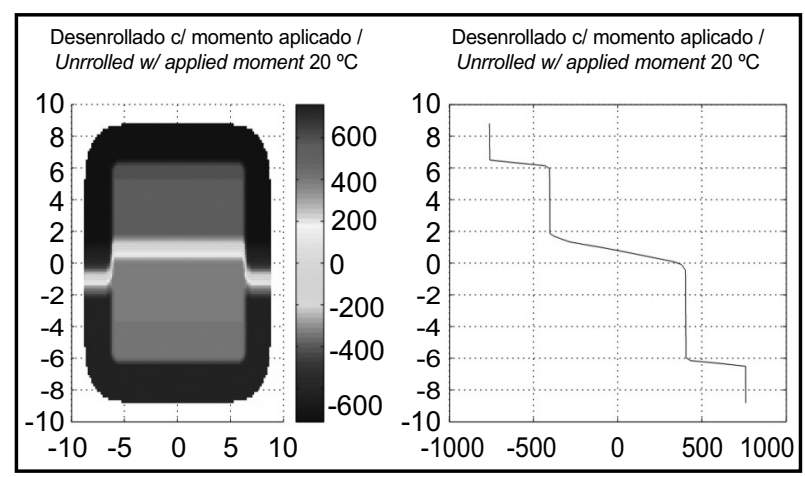

Figura 17. Distribución de tensiones después de aplicar una contra curvatura a la barra por enderezado de ésta. Contorno de la sección transversal y distribución de tensiones en el plano medio.

Figure 17. Stress distribution after applying counter-curvature for straightening. Cross-section contour and middle plane distribution.

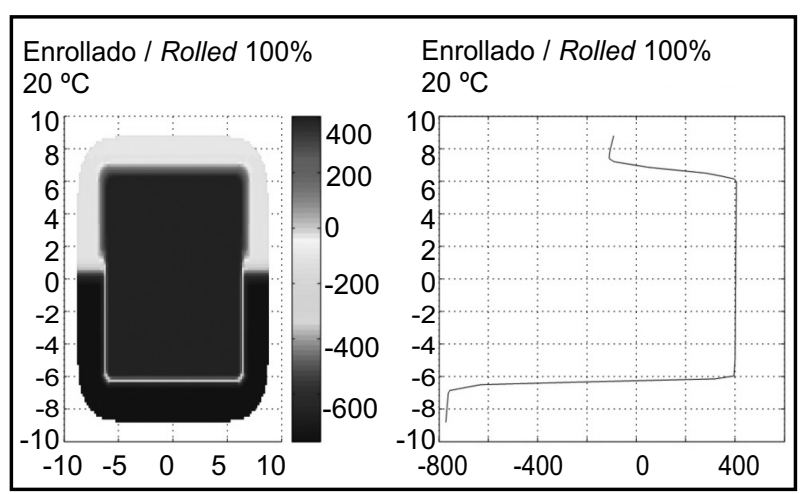

Figure 16. Distribución de tensiones en una barra curvada de $20^{\circ} \mathrm{C}$. Contorno de la sección transversal y distribución de tensiones en el plano medio.

Figure 16. Stress distribution on bended bar at $20^{\circ} \mathrm{C}$. Cross-section contour and middle plane distribution.

Straightening the bar implies applying a counter curvature subjecting the fibres to opposite yielding as seen in Figure 17. After releasing the bar, the final stress distribution of the straight bar is shown in Figure 18. Residual stresses result from the whole process; these may be as high as $350 \mathrm{MPa}$ in the ferrite-pearlite core and $200 \mathrm{MPa}$ in the martensite crown. It should be noted that, instead of having uniform compression in the crown and tension in the core, as results from TEMPCORE ${ }^{\circledR}$ process of a straight bar, in the case of a rolled bar, the effect of winding and straightening produces tension and compression stresses in both core and crown. These

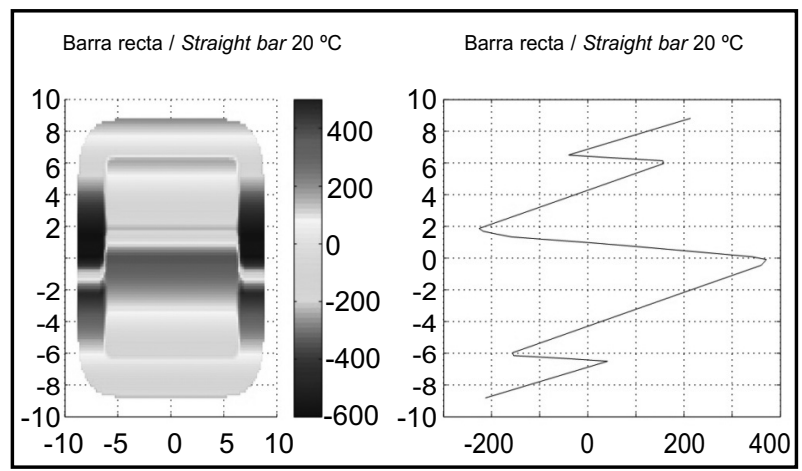

Figura 18. Distribución de tensiones en una barra recta. Contorno de la sección transversal y distribución de tensiones en el plano medio.

Figure 18. Stress distribution in straightened bar. Cross-section contour and middle plane distribution. 
núcleo, el proceso de enrollado y enderezado de la barra induce tensiones y compresiones tanto en la corona como en el núcleo de la barra. Las tensiones son autoequilibradas y puede observarse que, a fin de satisfacer el equilibrio de momentos, las tensiones en el núcleo, que tienen menor brazo mecánico, deben ser mayores que en la corona.

Las Figuras 19 y 20 muestran la distribución de deformaciones plásticas $\left(\varepsilon_{\mathrm{p}}\right)$ y potencial plástico $(\alpha)$, respectivamente, para el enderezado de barras. La deformación plástica tiene una distribución irregular a lo largo de la sección; sin embargo, el potencial plástico $(\alpha)$ muestra una distribución simétrica alrededor del centro de la sección. La combinación de ambos parámetros determina el nuevo límite elástico para cada fibra. Por lo tanto, existen en la sección puntos que plastifican a diferentes niveles de carga. Los valores del potencial plástico son altos, especialmente en la corona.

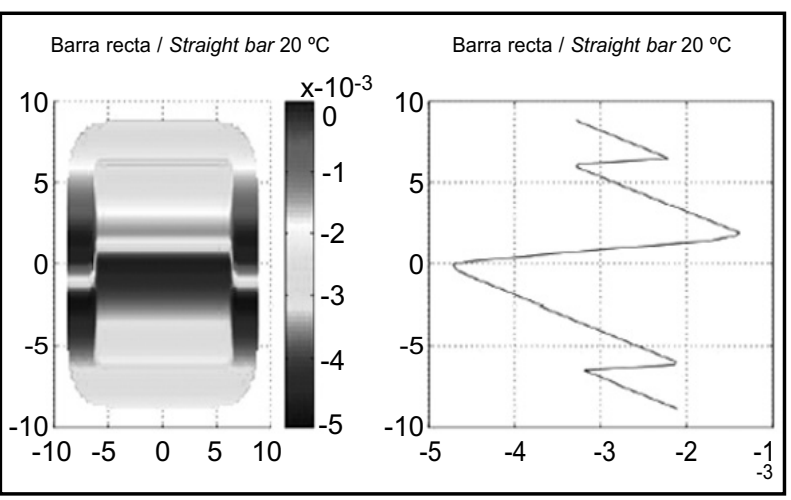

Figura 19. Distribución de deformaciones plásticas (ep) después del enderezado. Contorno de la sección transversal y distribución de tensiones en el plano medio. Figure 19. Distribution of plastic strains (ep) after straightening. Cross-section contour and middle plane distribution.

Cuando la barra se somete a un ensayo de tracción simple, el estado tenso-deformacional de cada fibra afecta la curva $\sigma-\varepsilon$ observada. La Figura 21 muestra la distribución de tensiones para el punto en el que se pierde la linealidad $\left(f_{n l}\right)$. Se puede observar cómo en ese punto la plastificación afecta a diversas fibras de la parte central del núcleo ferrítico-perlítico en la zona donde se produce el máximo valor de tensión residual, que se identificó en la Figura 18. La Figura 22 muestra la distribución de tensiones para el punto en el que se inicia la plastificación según la normativa. Para este nivel de carga, hay diversos puntos plastificados tanto en al núcleo como en la corona, sin embargo, existen algunos puntos aún en rango elástico ya que su tensión residual de partida favorece que plastifiquen para un nivel de carga mayor. Por tanto, el escalón de cedencia muestra un leve endurecimiento antes de que la primera fibra entre en la zona de endurecimiento por plastificación. stresses are self-balanced and it can be seen that in order to fulfil the moment equilibrium, the stresses in the core, with less lever arm, should be higher than the stresses in the crown.

Figs. 19 and 20 show the distribution of plastic strain $\left(\varepsilon_{p}\right)$ and plastic potential $(\alpha)$ for the straightened bar. Plastic strain shows an irregular distribution along the section, on the other hand, plastic potential $(\alpha)$ shows a symmetric distribution along the section's centroid. It is worthy to note that the combination of these two parameters determine the new yielding stress of each fibre; therefore, different points of this section will yield at different load levels. On the other hand, plastic potential shows high values, especially in the crown. Since this variable is nonrecoverable, it will be determinant for the maximum ductility of these fibres as will be seen bellow.

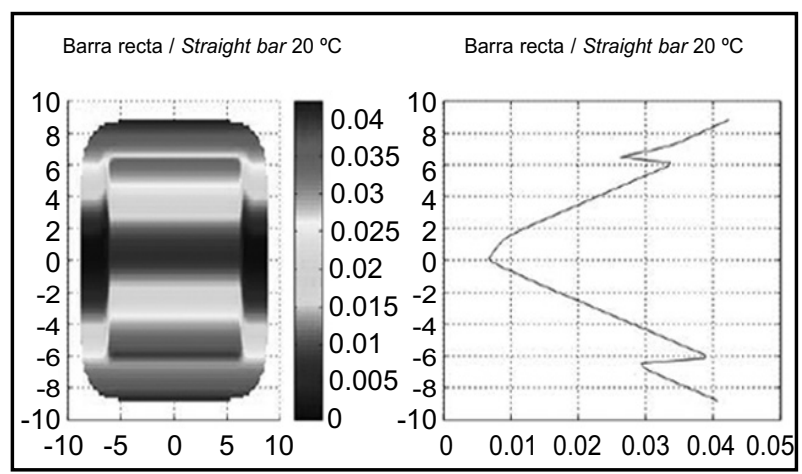

Figura 20. Distribución del potencial viariable plastic (a) después del enderezado. Contorno de la sección transversal y distribución de tensiones en el plano medio.

Figure 20. Distribution of plastic potential variable (a) after straightening. Cross-section contour and middle plane distribution.

Figure 21 shows the distribution of stresses for the point of loss of linearity $\left(f_{n l}\right)$. It can be seen that at this point yielding has extended along several fibres of the ferritepearlite core centred on the region of peak residual stress that was identified in Figure 18. Figure 22 shows the distribution of stresses for the point identified as yielding stress according to normative definition. Note that for this load some fibres have yielded, especially in the core with a yielding stress of $400 \mathrm{MPa}$. Some fibres are still in the elastic range; hence, the yielding plateau in the stress-strain curve of the whole bar will show a slight hardening branch immediately after yielding. 


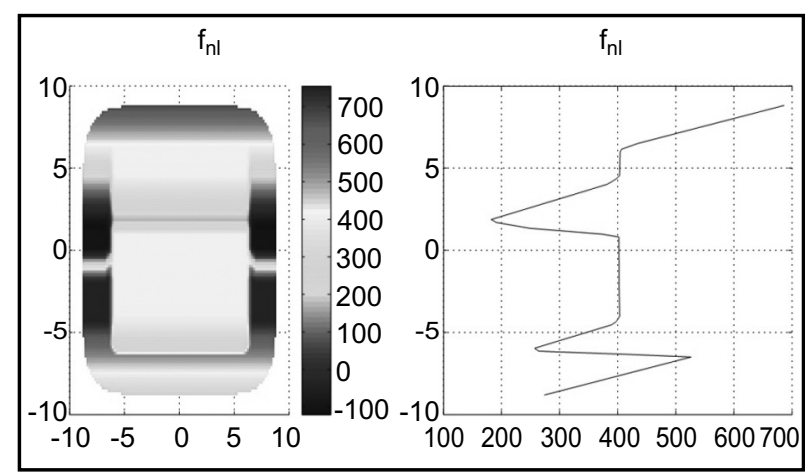

Figura 21. Distribución de tensiones al inicio del tramo no-lineal $\left(f_{n 1}\right)$. Contorno de la sección transversal y distribución de tensiones en el plano medio.

Figure 21. Stress distribution at point begining of non-linearity regim $\left(f_{n} l\right)$. Cross-section contour and middle plane distribution.

La distribución de tensiones para el nivel máximo de tensión $\left(f_{\max }\right)$ es la indicada en la Figura 23 . Como resulta evidente, las fibras de la corona exterior con un potencial plástico mayor, se encuentran ya en la zona de reblandecimiento. Todos los puntos de la corona se encuentran en la zona de endurecimiento por plastificación o mas allá y posteriormente empezaran a fracturarse. Por otro lado, las fibras de núcleo, con más ductilidad, no son capaces de sostener el nivel de carga que finalmente caerá hasta producirse la rotura de la barra.

\section{ESTUDIO PARAMÉTRICO}

Una vez identificados los diversos fenómenos de carácter no lineal a partir del análisis de una barra de referencia, se lleva a cabo un estudio paramétrico para identificar las variaciones más significativas de las propiedades mecánicas, en función de la variación del diámetro de la barra para diferentes cocientes diámetro de barra-radio de espira $(\varnothing / \mathrm{R})$. La Figura 24 muestra diversas curvas

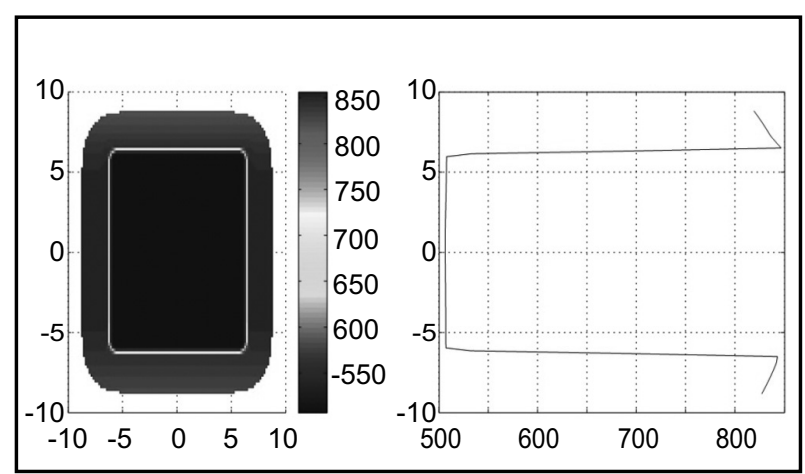

Figura 23. Distribución de tensiones para valores de tensión mayores. Contorno de la sección transversal y distribución de tensiones en el plano medio.

Figure 23. Stress distribution at maximum stress. Cross-section contour and middle plane distribution.

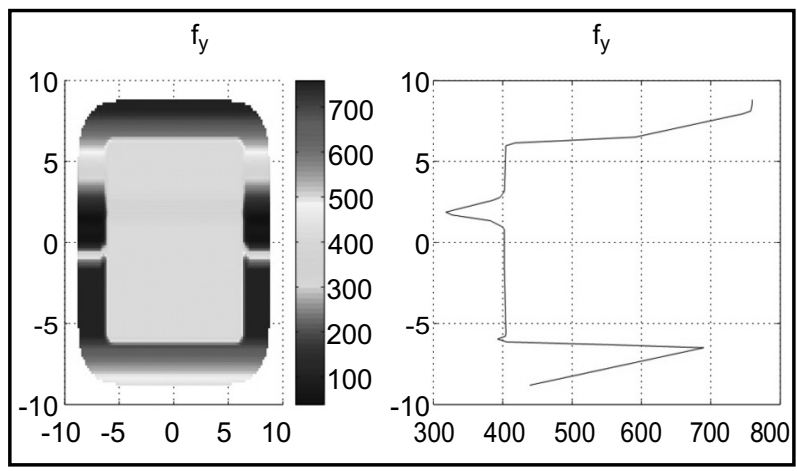

Figura 22. Distribución de tensiones para el valor de plastificación normativo. Contorno de la sección transversal y distribución de tensiones en el plano medio.

Figure 22. Stress distribution at standard yielding stress. Cross-section contour and middle plane distribution.

The distribution of stresses in the cross-section when the maximum medium stress $\left(f_{\text {max }}\right)$ is reached is shown in Figure 23. It is evident that crown fibres with the highest plastic potential are already in a softening process. Crown fibres are fully yielded and in the hardening branch. After this point, higher strength crown fibres will subsequently soften and separate while the core ductile fibres are not capable of sustaining the maximum load which eventually will be reduced until failure.

\section{PARAMETRIC STUDY}

Once the non-linear phenomena taking place have been identified and quantified for the reference bar, a parametric study is performed in order to identify the more relevant variations on the mechanical properties affected by variations of the bar diameter to spiral radius ratio $(\varnothing / R)$. In this sense, Figure 24 shows different stress-strain curves for different spiral ratios. The more

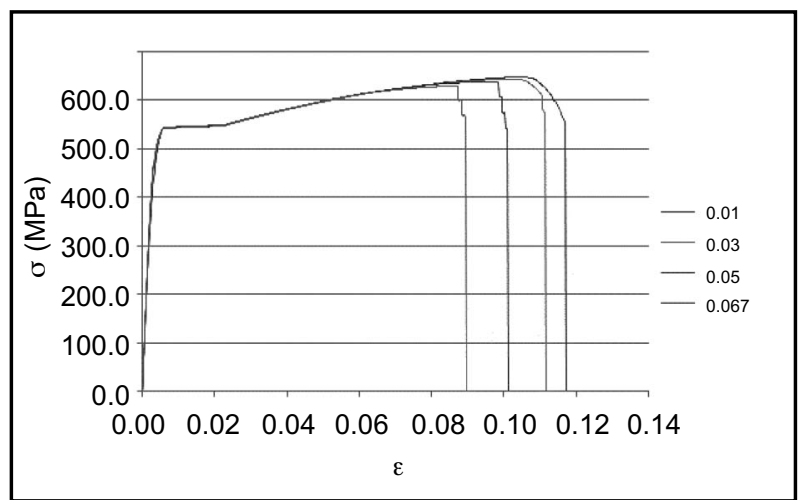

Figura 24. Curvas tensión-deformación para diversos ratios $\varnothing / R$. Figure 24. Stress-strain curves for different $\varnothing / R$ ratios. 
tensión-deformación en función del cociente $\varnothing / R$. La influencia más destacable es la reducción de la ductilidad de la barra con el aumento del diámetro de ésta o con la disminución del radio de la espira. Este aspecto es muy relevante de cara a la denominación de una barra como de alta ductilidad (SD).

Por otro lado, la Figura 25 muestra un detalle de la zona de plastificación donde se puede observar cómo la tensión de plastificación incrementa con el cociente $\varnothing / R$. Esta variación es menos importante que la observada en ductilidad o no es suficientemente significativa para afectar a la denominación del acero.

Para producir diámetros mayores en bobina, de manera que no se afecte la denominación del grado de ductilidad de la barra enderezada, se debe controlar el valor del radio mínimo de espira permitido en la bobina. Este estudio ha permitido determinar la pérdida de deformación bajo carga máxima para lograrlo. La siguiente expresión [20] ajusta con muy buena aproximación la pérdida de ductilidad dentro del rango $0 \leq \varnothing / R \leq 0.1$. Los resultados de la expresión se comparan con los resultados de la simulación numérica en la Figura 26.

$$
\frac{\Delta \varepsilon_{\max }}{\varepsilon_{\max }}=\left\{\begin{array}{cc}
0 & \text { si } 0 \leq \frac{\emptyset}{R} \leq 0.01 \\
-55\left(\frac{\emptyset}{R}-0.01\right)^{2} & \text { si } 0.01 \leq \frac{\emptyset}{R} \leq 0.1
\end{array}\right.
$$
ductility bars (SD). standard denomination. Figure 26.

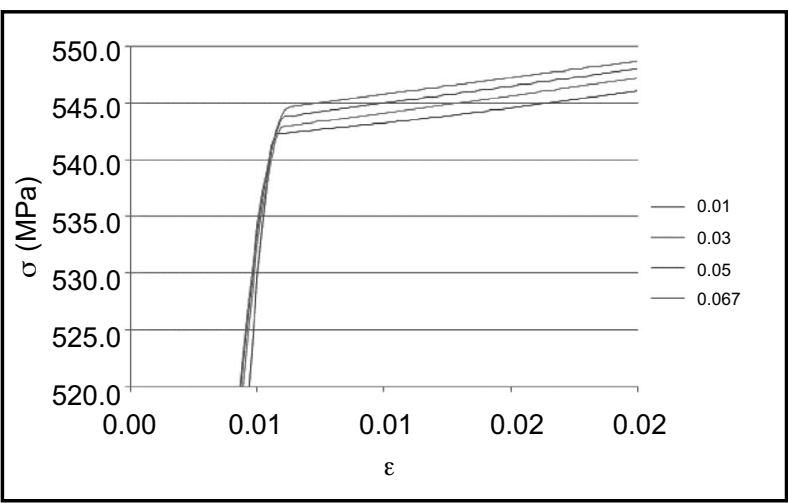

Figura 25. Zoom de la zona del punto de plastificación para diversos ratios $\varnothing / R$.

Figure 25. Zoom view of the yield point for different $\varnothing / R$ ratios.

\section{CONCLUSIONES}

En el proceso de fabricación de las barras enrolladas bajo proceso TEMPCORE®, éstas se ven sometidas a historias de carga y temperatura de carácter complejo que generan tensiones residuales. Adicionalmente los procesos de enrollado y enderezado a temperatura ambiental implican la aparición de tensiones residuales y de plastificación en noticeable influence is the reduction of the bar ductility for increasing bar diameter or lower spiral radius. This aspect is relevant for the denomination of special high

On the other hand, Figure 25 shows a close view of the yielding zone where it can be seen that the yielding stress increases with the $\varnothing / R$ ratio. This variation is however less important than the observed effect in ductility, and not significant enough to affect the

In order to safely produce higher bar diameters in coils, so that the ductility grade of the straightened bar can be maintained, care should be taken of the minimum spiral radius allowable in the coil. After this study the expected loss in the strain under maximum load can be determined. The following expression, [20] obtained by a least square fitting, was found to adequately fit the ductility loss within the range $0 \leq \varnothing / R \leq 0$. 1 , see

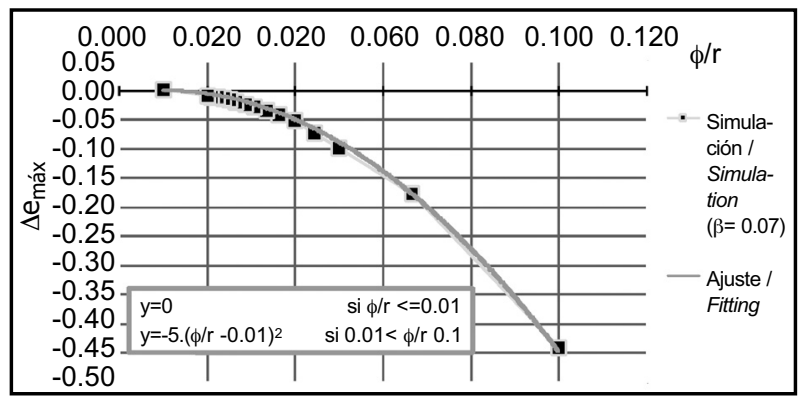

Figura 26. Pérdida de ductilidad como función del ratio $\varnothing / R$. Figure 26. Ductility loss as a function of $\varnothing / R$ ratio.

\section{CONCLUSIONS}

During manufacture, coils of TEMPCORE® reinforcing bars are subjected to complex load and temperature histories producing residual stresses. Further unrolling or straightening at environmental temperature induces plastification and residual stresses in the cross-section opposing to the ones due to winding. However, some 
zonas de la sección transversal contrarias a las originadas por el enrollado. Finalizado todo el proceso se obtienen picos de tensión, cercanos al valor de plastificación del material, dentro del núcleo dúctil ferrítico-perlítico.

Las tensiones residuales producidas por el proceso TEMPCORE ${ }^{\circledR}$ están asociadas principalmente al temple severo que induce compresiones en la corona martensítica y tracciones en el núcleo ferrítico-perlítico. El historial de tensiones y deformaciones del enrollado y enderezado modifica la distribución de tensiones residuales anterior, obteniéndose sobre la corona exterior tensiones de compresión y tracción indistintamente.

Se ha desarrollado un modelo numérico, calibrado experimentalmente, que permite identificar y cuantificar los efectos no-lineales que se producen en las fibras de la sección y la interacción existente entre ellos. El modelo se basa en una discretización de la sección por fibras y en un modelo constitutivo que reproduce un comportamiento con endurecimiento por plastificación mixto entre isotrópico y cinemático. Se ha definido un parámetro $\beta$ que varía entre 0 y 1 para modelizar el comportamiento por endurecimiento. Para un valor de $\beta=0$ el modelo reproduce el comportamiento puramente cinemático y $\beta=1$ representa un comportamiento isótropo. Este parámetro se calibró experimentalmente siendo el valor ajustado de $\beta=0,07$.

Las curvas tensión-deformación del núcleo ferrítico-perlítico fueron obtenidas experimentalmente mediante la eliminación mecánica de la corona exterior y ensayo de la barra resultante. Este material muestra un comportamiento muy dúctil con una deformación máxima del orden de 0,2 a 0,25; sin embargo, el límite elástico es menor que el valor nominal de la barra. La curva tensióndeformación de la corona martensítica exterior fue obtenida indirectamente a partir de los resultados obtenidos de ensayar una barra de sección completa y de los ensayos del núcleo. La deformación máxima del material es sensiblemente menor que la deformación total de la barra completa y su tensión de plastificación es un $40 \%$ mayor.

Los procesos de enrollado y enderezado de las barras modifican las propiedades de éstas, principalmente incrementando la tensión de plastificación en comparación con el valor normativo. El comportamiento puramente elástico se pierde para un 70-80\% del límite elástico al llegar algunas de las fibras de la sección a plastificar por la presencia de tensiones residuales. Estas variaciones no son de magnitudes importantes y no condicionan el grado del acero. Por otro lado, la ductilidad de la barra, cuyo grado normativo se basa en la deformación bajo carga máxima $\left(\varepsilon_{\max }\right)$, puede verse afectada de manera más notable. En general, la variable con peaks of stresses takes place after the whole process is finished, so that maximum stresses takes place in the higher ductile ferrite-pearlite core with values close to the yielding stress of that material.

Residual stresses produced exclusively by TEMPCORE® process are mainly due to cooling of the severe tempering producing compression on the martensite crown and tension in the ferrite-pearlite core. Stressstrain history of the winding and straightening process modifies this rather regular residual stress distribution; hence both compression and tension can be found on different zones of the crown.

A numerical model was developed and calibrated against experimental observation in order to indentify the nonlinear effects taking place in all fibres and the interaction among them. The model is based on a fibre discretization of the actual cross-section shape and a constitutive model developed in this study with mix isotropic and kinematic hardening. An internal parameter $(0 \leq \beta \leq 1)$ is used to define the actual hardening behaviour. Hence, varying $\beta$ from 0 to 1 the model changes from pure kinematical to pure isotropic; intermediate behaviour, more suitable of the real materials, are obtained with in-between values. The parameter was calibrated resulting that the best fit corresponds to $\beta=0.07$.

Stress-strain curves of the ferrite-pearlite core were determined from experimental tests in which the external crown was removed by mechanization. This material showed very ductile behaviour with maximum strains of the order of 0.2 to 0.25 ; however, the yielding stress is lower than the nominal yielding stress of the bar. The stress-strain curve of the exterior martensite crown was indirectly determined after testing the actual behaviour of the complete bar. The maximum strain of this material is only slightly lower than the overall strain of the complete bar and its yielding stress is $40 \%$ higher.

Properties of the straightened bar are modified by the process mainly by increasing the yielding stress according to standard normative definition. Pure linear elastic behaviour is slightly lost and a proportional limit exist approximately at 70\% 80\% of the yielding stress, as some fibres of the section reach yielding stress first because of the residual stress distribution. These variations are not of a significant magnitude and do not influence the grading of the steel. On the other hand, bar ductility, whose normative grading is based on the strain under maximum stress $\left(\varepsilon_{\text {max }}\right)$, can vary in a more significant sense. In general, it was found that the more 
mayor incidencia es la relación entre el diámetro de la barra y el radio de la espira $(\varnothing / \mathrm{R})$. Finalmente, gracias a un exhaustivo estudio paramétrico, se obtuvo una relación entre $\varnothing / \mathrm{R}$ y la pérdida de ductilidad producida. Dicha expresión es válida para el rango $0 \leq \varnothing / R \leq 0,1$; esto permite definir el radio de la espira de la bobina en el caso de fabricación de barra enrollada para diámetros grandes. Este resultado es especialmente útil cuando la ductilidad de la barra forma parte de su denominación normativa y es una de las características mecánicas a garantizar en el producto final enderezado.

\section{AGRADECIMIENTOS}

Esta investigación se llevó a cabo con el apoyo económico de la Empresa Española de Laminación SA (CELSA), a través de la Cátedra CELSA-UPC de Acero y Construcción. Los autores desean agradecer al personal del Laboratorio de Tecnología de Estructuras de la UPC su apoyo en la realización de los ensayos llevados a cabo en las campañas experimentales y a Noemí Duarte. influencing variable was the ratio of bar diameter to spiral radius $(\varnothing / R)$. After an extensive parametric analysis, a relationship between $\varnothing / R$ and the expected loss of ductility was obtained. This expression is valid for a range of $0 \leq \varnothing / R \leq 0$. 1. It can be used to control the coil size as higher nominal diameters are expected to be produced in this format. These findings are particularly relevant when bar ductility is part of the steel grading and a minimum strain at maximum stress needs to be guaranteed.

\section{ACKNOWLEDGEMENTS}

This research was conducted under the support of the Spanish Lamination Company (CELSA) through a $R+D+i$ project of the CELSA-UPC Chair of Steel and Construction ("Cátedra CELSA-UPC de Acero y Construcción"). Authors want to acknowledge the intense collaboration of the staff of the Structural Technology Laboratory of the UPC and Noemi Duarte.

\section{BIBLIOGRAFÍA / BIBLIOGRAPHY}

(1) AENOR. UNE-EN-ISO 15630-1:2003: "Aceros para el armado y pretensado del hormigón. Método de ensayo. Parte 1: Barras, alambres y alambrón para el hormigón armado" (2003).

(2) Comisión Permanente del Hormigón: "Instrucción de Hormigón Estructural. EHE-08", Ministerio de Fomento (2008), pp. 722.

(3) Bontcheva, N.; Petzov, G.: "Total simulation model of the thermo-mechanical process in shape rolling of steel rods", Computational Materials Science, vol. 34 (2005), pp. 377-388. http://dx.doi.org/10.1016/j.commatsci.2005.01.009

(4)Yong-Soon, J. D. C.; Byung-Min, K.: "Application of the finite element method to predict microstructure evolution in the hot forging of steel", Journal of Materials Processing Technology, vol. 101 (2000).

(5) Nikolau, J.; Papadimitriou, G.: "Microstructures and mechanical properties after heating of reinforcing 500 MPa class weldable steels produced by various processes", Construction and Building Materials, vol. 18 (2004), pp. 243-254. http://dx.doi.org/10.1016/j. conbuildmat.2004.01.001

(6) Zheng, H.; Abel, A.: "Fatigue properties of reinforcing steel produced by TEMPCORE Process", Journal of Materials in Civil Engineering, 11 (2) (1999), pp. 158-165. http://dx.doi.org/10.1061/(ASCE)0899-1561(1999)11:2(158)

(7) National Institute of Standards and Technology (NIST): "Mechanical properties of structural steels". NIST NCSTAR 1-3D, Department of Commerce, USA (2005), pp. 288.

(8) Comité Européen de Normalisation (CEN): "Eurocode 3: Design of steel structures. Part 1.2: General rules - Structural fire design". Comité Européen de Normalisation, prEN 1993-1-2:02/2002 (2002).

(9) Marí, A. R.; Bairán, J. M.: "Evaluación de los efectos estructurales del deterioro, reparación y refuerzo, mediante análisis no lineal evolutivo". Hormigón y Acero, vol. 60, no 254 (2009), pp. 51-63.

(10) Marí, A. R.: "Nonlinear geometric, material and time dependent analysis of three dimensional reinforced and prestressed concrete frames", Report No. USB/SESM-84/12. U.C. Berkeley, Berkeley, June, 1984. 